\title{
Political agency of indigenous peoples: the Guarani-Kaiowa's fight for survival and recognition
}

Antonio A. R. loris ${ }^{1}$

'Cardiff University, School of Geography and Planning, United Kingdom

\begin{abstract}
The article examines the survival strategies and political reactions of indigenous groups in areas of agricultural frontiers that are strongly influenced by cultural symbols, family bonds and land-based responses. It is discussed the unique socio-spatial trajectory of indigenous peoples and, in addition, a typology of the indigenous space is proposed. The analysis is focused on the emblematic example of how frontier making was experienced by the Guarani-Kaiowa of South America. The wisdom and resistance of Guarani-Kaiowa groups derive from the simultaneous ethnicisation of space and spatialisation of culture. They have shown latent geographical agency shaped by religious practices, strong family ties and the ability to internally negotiate the return to their original areas. There are many lessons to be learned, in particular the talent to absorb the increasing and dissimulated brutality of frontier making and, at the same time, voice their political demands, form solid strategic alliances and coordinate land-recovery initiatives.
\end{abstract}

Keywords: Guarani; Kaiowa; land grabbing; retomada; culture; religion. 


\section{Agência política dos povos indígenas: a luta dos Guarani-Kaiowá por sobrevivência e reconhecimento}

\section{Resumo}

O artigo examina as estratégias de sobrevivência e reações políticas de grupos indígenas em áreas de fronteiras agrícolas, que são fortemente influenciadas por símbolos culturais, vínculos familiares e respostas vinculadas ao apego pela terra. Discute-se a especificidade da trajetória sócio-espacial dos povos indígenas e, além disso, propõe-se uma tipologia do espaço indígena. A análise é dedicada especialmente ao exemplo emblemático da fronteira vivida pelos Guarani-Kaiowá da América do Sul. A sabedoria e a resistência dos grupos GuaraniKaiowá derivam da simultânea etnização do espaço e da espacialização da cultura. Essa experiência demostra uma agência geográfica moldada por práticas religiosas, fortes laços familiares e a capacidade de negociar internamente o retorno às suas áreas originais (retomadas). Há muitas lições a serem aprendidas, em particular a capacidade de absorver a brutalidade crescente e dissimulada que caracteriza o avanço da fronteira e, ao mesmo tempo, de expressar demandas políticas, formar alianças estratégicas sólidas e coordenar iniciativas de recuperação das áreas perdidas para o desenvolvimento.

Palavras-chave: Guarani; Kaiowá; grilagem; retomada; cultura; religião. 


\section{Political agency of indigenous peoples: the Guarani-Kaiowa's fight for survival and recognition}

Antonio A. R. loris

\section{Spiralling paradoxes: the indigeneity of frontier making}

Socio-spatial frontiers are not just remote areas where new socio-economic relations are imposed on top of previous conditions. The space of the frontier has a complex, multifaceted configuration in which both the hyper-new and what is considered obsolete coalesce. Following development and modernisation trends, frontier making brings the potentiality and, more importantly, the long-lasting problems of core spatial areas to the emerging frontier spaces (Ioris 2018a). Among the many peoples affected, indigenous groups - also described as natives, ancestral peoples, first nations, the Fourth World or aborigines - have vividly experienced the complex interplay of clashes, violence and resistance due to their brutal insertion in the process of frontier making. Discourses of sovereignty and legitimacy certainly underwrote "settler colonialism's desire to uproot and destroy the place-based autonomies of Indigenous peoples in the relentless acquisition of ever more land and resources" (Larsen and Johnson 2017: 4). The colonial project was a coordinated attempt to affirm the power of the European nation states and create sources of wealth and economic rents out of the subjugation or displacement of indigenous peoples. Survivors were usually forced to seek refuge in remote areas, already occupied by other groups, and which would later be incorporated again as new frontiers. Particularly in Latin America, the tragic history of indigenous groups is well known, written under the auspices of colonisation and following the pattern of a racialised power exerted both by the European powers and by governments in Latin America after independence (Quijano 2008).

Mariátegui (2007), almost a century ago, rightly denounced the idea that the 'Indian question' in the region was primarily a problem of the land ownership regime. However, the process of frontier making was a devastating blow that went far beyond land or resource grabbing: it has been a true phenomenon of worldgrabbing in the sense that it comprises an attempt to reduce lives and landscapes to the language of money and profit. Unlike migrant peasants, miners, construction workers or farmers, indigenous peoples had already been living in the areas converted into frontiers, which raises an important question regarding how they differ from other subaltern groups involved in frontier-making activity. Martins (1995) argues, based on studies in the Amazon, that the condition of squatters at the frontier results directly from the contradictions of capital, given that squatters must be removed from disputed areas for private property and wage labour to flourish. For that reason, the "squatter is product of the very logic of the expansion of capital; the Indian is not. The squatter can be reimbursed for his work, as a means to remove him from the land pursued by the farm or the company... The Indian cannot, in principle, be reimbursed to leave his land: this land is not just a thing, an object... it doesn't have the attribute of thing and commodity. The land is sacred, it is the base of the tribal organisation" ( $\mathrm{p}$. 117). On the other hand, the political condition of indigenous peoples is not entirely different and, just like peasants, squatters and similarly marginalised people, their existence is intensely transformed by their immersion in frontier making (Ioris 2019). The dialectical result is that indigenous groups retain their cultural heritage and strict relations with the land, but at the same time they share important patterns of 
mistreatment and marginalisation with other groups. As pointed out by Anthias (2017), indigenous territories are neither separate from, nor entirely subsumed by, capitalist development processes, but rather subject to multiple land values, ontologies and business investments.

Therefore, the participation of indigenous peoples in frontier making, although widely studied throughout the world, still demands further conceptual and empirical scrutiny. The focus of most texts is on the systematic imposition of a new socio-spatial order by the settler states on indigenous peoples, at the expense of preexisting institutions such as common ownership of land, a self-sufficient economy, nomadic stateless life, and spiritual bonds to the land (Yiftachel and Fenster 1997). Authors discuss how the original inhabitants of the territory were obliged to retreat in the face of the advancing new frontier, forcing them into situations of acute exploitation, deprivation and overcrowding. However, this literature has frequently overlooked the perceptions, the inventiveness, the active reactions and the complex ontology of indigenous peoples. It is really only since the 1970s that indigenous voices and political subjectivity have started to attract better recognition. Indigenous groups are the quintessential targets of resource colonialism and the theft of land and resources (Parson and Ray 2018), but their history and agency did not end with the loss of their land and the decimation of members of their society. On the contrary, they continue to claim an indigenous identity in daily life activities and maintain attachments to places under difficult circumstances. Consequently, the indigeneity of frontier making requires post-colonial sensibilities and a recognition of the political significance of culture in space. Beyond essentialist and reductionist positions, there should be a concern for the politics of race, as well as questions of representation and the ideological construction of various racialised 'others,' in favour of conceptualisations that are time and place specific (Jackson and Penrose 1993).

Our goal is not to review the geography, culture and history of indigenous groups in any great detail, but to examine their survival strategies and insurgent geographies based on cultural symbols, family bonds and land-based responses to the excesses of frontier making. This is directly inspired by the 'cultural materialism' of Raymond Williams, which entails the mobilisation of culture against modern society with a creative reconciliation between multiple sensitivities and an anti-capitalist critique (Löwy and Sayre 2018). The main intention is to make use of the conceptualisation of frontier making to understand the socio-spatial trajectory and, in addition, propose a typology of indigenous spaces. This article aims to foster a dialogue between anthropologists and geographers through an examination of the emblematic example of how frontier making was experienced by the Kaiowa, one of the Guarani peoples of South America (for background information, refer among others to Brand 1997; Chamorro 1998; Clastres 1974; Melià 2004; Pereira 2016). The Guarani population is estimated to comprise around 280,00o individuals, 85,000 of whom live in Brazil, 80, ooo in Bolivia, 61,000 in Paraguay and 54,000 in Argentina (EMGC 2016). They are normally described as belonging to four clusters: Kaiowa (the denomination used in Brazil, also known as Paĩ-Tavyterã in Paraguay), Nhandeva (also described as Ava-Guarani), Mbya (in the south of Brazil, Paraguay and Argentina) and Chiriguanos (in the Andean foothills in Bolivia). The majority of the Kaiowa-Guarani, around 45,00o people, live in the Brazilian state of Mato Grosso do Sul, around and to the south of the city of Dourados, often sharing reserves and lands with other ethnic groups, such as the Nhandeva-Guarani and Terena. Figure 1 shows the population distribution of the Guarani peoples of South America. 


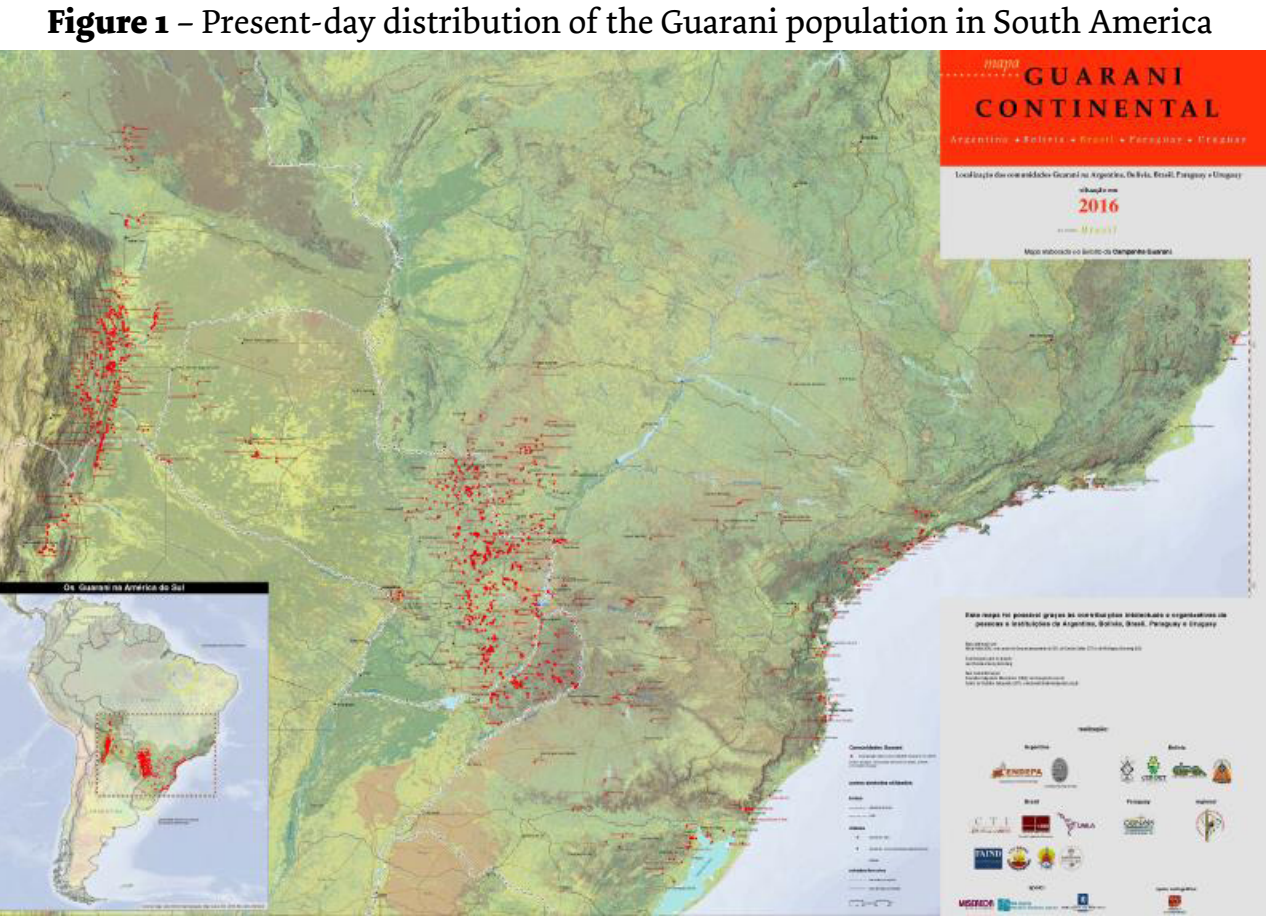

(source: EMGC 2016)

Disruption and aggression towards Kaiowa communities is a long-established phenomenon, originally related to the process of colonisation and aggravated during moments of territorial dispute, such as during the Paraguay War (1864-1870), the bloodiest conflict in the continent's history, which took place right in the middle of Guarani territories. From the end of the nineteenth century, after the war, explorers and companies were attracted to the region due to its abundant natural resources, good agricultural land and strategic location in terms of river navigation, relative proximity to the main economic centres, and the geopolitical need to occupy international border areas (Ioris 2012). Economic activity has intensified in recent decades due to the expansion of export-oriented agribusiness and increasing land speculation. One crucial driving-force behind the various periods of colonisation and economic production has been the distressing levels of violence against individuals and families, particularly in areas of acute agrarian conflict between farmers and indigenous collectives. Space-based violence is a major, ongoing reality, not a singular event that happened in the past in other words, the oppression of indigeneity continues to pervade the geographical present (Radcliffe 2017). Indigenous groups are systematically harassed by the police and by private militias hired by landowners (known as pistoleiros, i.e. 'hired guns'). Professional militias are typically registered as private security firms, managed by former military police officers and tacitly accepted by a pliant judiciary. Even in the regularised indigenous reserves, the population feel discriminated against and marginalised by the rest of society, leading to growing frustration and social unrest. Kaiowa-Guarani communities have presented alarming rates of suicide (555 between 2001 and 2011, according CIMI) and premature deaths, including children hit by cars, are much higher among indigenous families than among the general population. 
Out of the total number of 1,119 murders of indigenous individuals in Brazil between 2003 and 2017, 461 cases (41.19\%) occurred in Mato Grosso do Sul (CIMI 2018a), particularly affecting the Kaiowa and involving

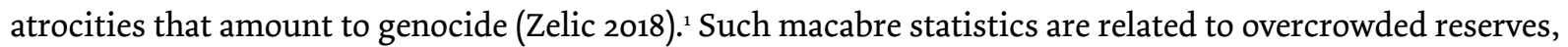
chronic malnutrition, usurpation of ancestral lands, and disregard or attacks from agribusiness farmers, mainstream politicians, authorities and the business community. During our research in Mato Grosso do Sul, discrimination against Kaiowa children and adults was disturbingly common in shops and streets, in addition to mistreatment by civil servants. Court cases often take decades to be decided, even when the rights of the indigenous groups are clearly defined and easy to ascertain. More than economic, political and environmental refugees, the Kaiowa are expatriates in their own territory, as they have been systematically marginalised from the benefits of development and forced to live in newly created, and constantly reinforced, socio-spatial edges. Despite using social media to promote their cause, the Kaiowa are much less visible, for example, than national and international NGOs because of internet algorithmic filtering, which deliberately excludes some types of political discourse, segregates social groups and suppresses divergent perspectives (Ochigame and Holston 2016). Racism is concrete, structural and widespread (despite being officially a serious crime under national legislation) and, in this regard, the Kaiowa-Guarani share many of the troubles affecting other indigenous populations, peasants and the urban poor throughout the country.

The shocking poverty and terrible suffering of the Kaiowa-Guarani represents the unpleasant side of the agribusiness-based regional economy and corrodes the supposed legitimacy of development and the existence of the democratic rule of law in the region. Agribusiness causes a range of problems for the world at large, but on the frontier it is even more belligerent and irrational, compensating for and filling lacunas in state and civil society with the rhetoric of 'development' when, in reality, the region has been launched into a state of low-intensity agrarian warfare between farmers and indigenous groups. Nonetheless, the spatial condition of the Kaiowa is a true riddle for regional economic planning: on the one hand, their land, resources and labour force are central to the very success of the frontier; on the other, the existence of indigenous groups means that the worst side of frontier making is still active and constantly reinforced by the unresolved incongruity between cultures and cosmologies. The result is that indigenous groups like the Kaiowa are the embodiment of the spatial frontier and also its most explicit subversion. The Kaiowa-Guarani articulate a resistance against political hegemony, an ability to operate in the interstices of the state apparatus, and a capacity to attract support from a heterogeneous array of organisations. This can be described as 'latent geographical agency.' Before examining the specific situation of the frontiers lived and transgressed by the Kaiowa, it is important to reflect upon the multifaceted condition of indigenous peoples and the related challenges involved in conducting research from a critical and ethical perspective.

\section{Making sense of the indigeneity of frontier making}

In this section we ponder how to properly consider the deeply politicised condition of indigenous groups at the frontiers of economic development. Our reflection is closely associated with the emerging "critical geographies of indigeneity" (Radcliffe 2017), meaning, in particular, an appreciation of landscape as a framework for addressing basic human rights - or, in other words, the role of a 'right to the landscape' in the movement towards justice, dignity and wellbeing, integrating the spiritual and cultural values of land and

\footnotetext{
Today Brazil contains 305 indigenous peoples, speaking 274 different languages (there were an estimated 5,00o groups in 1500 , the year of the Portuguese conquest), and occupy about $13 \%$ of the national territory (although $97 \%$ of this area is in the Amazon). Mato Grosso do Sul has the second largest indigenous population, but the worst allocation of land in the country: the population density is 10.18 inhabitants $/ \mathrm{km}^{2}$, which is $40 \%$ more dense than among the non-indigenous population. In the case of the Kaiowa, this reaches 34 inhabitants $/ \mathrm{km}^{2}$ according to data presented by Zelic (2018).
} 
local communities (Egoz et al. 2011). The landscape becomes part of what people are through everyday life experiences, and indigenous people create meaningful relationships and connections with land as their main source of survival (Ingold 1993). To fully grasp this fact, it is necessary to acknowledge the long positivistic tradition and colonial foundations of Western knowledge, going back to the nineteenth century and even earlier, typically focused on areas of high biodiversity and abundant natural resources (MacDonald 2017). As pointed out by Coombes et al. (2014: 845), working with indigenous peoples has stretched "presumptions about appropriate modes of engagement and representation... that challenge reaches the heart of the enterprise to question the very purpose of research." Among other methodological and epistemological consequences, this means conducting research with and for the benefit of indigenous communities, allowing the expression of their own voices and their involvement in the interpretation of findings, rather than the conventional research on these communities conducted for the benefit of non-indigenous scholars and government agencies. In addition, and similar to feminist, anti-racist and queer movements, indigenous geography opens up the prospect of decolonising and reimagining wider horizons and functions for/of geography (Panelli 2008). As MacDonald (2017) splendidly observes, the research process is even more important than the immediate outcomes.

Many social scientists have demonstrated a growing commitment to embrace reflexive methods and deal with the politics of representation and the relational basis of critical research (Smithers Graeme and Mandawe 2017). This represents a challenging but rewarding attempt to remove prejudices and learn together through, for instance, participatory research within fluid situations fraught with injustices and ongoing territorial disputes. Several key aspects deserve particular attention, starting with ethical questions. Despite the debate and the concerns about research ethics, there remain important barriers that continue to limit understanding of indigenous landscapes affected by the pressures of economic development. Among the thousands of Kaiowa in Mato Grosso do Sul, the majority live in the congested reserves and around a quarter live in urban areas or in encampments along the roads. Theirs is a very unsettled and painful situation that continues to evolve through survival strategies amid threats of assimilation, annexation and extinction. Socio-cultural information about the Kaiowa is, therefore, deeply contingent upon specific space making circumstances, exacerbated by recurrent conflicts, the need to maintain family networks and external alliances, and the challenge to make sense of - and survive - in-between-world situations. The Kaiowa-Guarani have skilfully mobilised their memories, imaginaries and cultural expressions towards acts of resistance and spatial practice, and their involvement in any research project is seen as part of the struggle and a search for allies. As a result, researchers find themselves 'in between worlds' and are irrevocably transformed by the experience (Larsen and Johnson 2012). Researchers deal with accumulated tensions and passionate discourses, which often bring them to the centre of the struggle. It is a movement away from representing the Other and towards collective problem-solving, activism and advocacy (Coombes et al. 2014). The researcher occupies a specific location within the broad socio-political context of their research and must responsibly handle how this positionality and associated privileges shape the construction of knowledge (Smithers Graeme and Mandawe 2017).

Ethical concerns must be sensitive and creatively engage with the past trajectory, the current political situation and the aspirations of societies amid land-based disputes with uncertain prospects. This is clearly important in terms of the confidentiality of social and personal information, and the constant risk of revealing details about leaders and their strategies, which could undermine action or influence public perception. It could likewise worsen internal divisions among indigenous families or groups, as well as between them and their traditional allies (churches, unions, NGOs, etc.). Riddell et al. (2017) list several crucial requirements for conducting ethical research, such as the informed and autonomous engagement of indigenous participants, recognising their ownership, control, assessment and possession of knowledge, respecting their intangible cultural property (i.e. language and traditions), reciprocity and inter-relational accountability. It means that the study of indigenous life cannot be contained within the narrow boundaries of non-indigenous 
science and reasoning, while simultaneously the basic terminology (i.e. indigeneity, aboriginality, colonial dominance, etc.) is highly contested. In the case of the Kaiowa, it is also necessary to consider their acute political situation and how they mobilise culture and religion to recover lost landscapes. What is needed is more than the usual participatory action research, but rather an engaged research approach that recognises local systems of knowledge and practice as fully authoritative and the actors involved as sufficiently competent to design, conduct and evaluate the research in which they are involved. This eschews what is happening with supposedly inclusive techniques, such as participatory mapping, now being incorporated into policymaking by government agencies and multilateral organisations. The indigenous participants must be more than informants or collaborators: they should be treated as co-researchers, co-ethnologists, co-creators.

Researchers must establish trusted connections with real people, without romanticising events or political leaders - that is, avoid perpetrating the 'hyperreal Indian' projected by many NGOs, a fantasy that reinforces the simulacrum of indigenous people as supposedly pure, ecological, stoic, unadulterated (Ramos 1994). Anthropological research has specifically demonstrated that the notion of the Kaiowa person emerges from relations across wider categories of their society: it is an intense dialectic between the self and their collective condition (hence their discrimination against single adult males). Among other issues, it is problematic to think of clear epistemological distinctions between approaches loosely identified as 'Western' and 'indigenous,' since in actuality both are polyvalent and polyvocal realms of discourse, just as indigenous people live within the framework of Western cultures (Shaw et al. 2006). Indigenous cultures and identities are fluid, their narratives and engagement with place and space are mutable, not linear; all this invites and prompts experimentation, innovation, affection and partnerships (Coombes et al. 2011; Murton 2012; Ramos 2018). Related to this fact, the Kaiowa find it unacceptable for researchers not to provide clear feedback or some concrete benefit back to them in relation to their struggle for recognition, rights and land. As one interviewed anthropologist pointed out, the research effort needs to recognise that the political demands of indigenous peoples are complex, multiple and constantly changing because of emerging problems. The responsibility of the researcher is to conduct objective research, to the best of their capacity, while at the same time responding to the expectation of a supportive and worthwhile interaction. The geographical trajectory of the Kaiowa encapsulates disputes and reactions that are common to other indigenous groups and even peasant communities throughout South America, but they have also experienced unique challenges related to their location, specific geographical settings and particular involvement in the wider process of modernisation through regional development.

While they expect support from researchers, the Kaiowa are not desperately begging for help from nonindigenous actors. On the contrary, and in common with other contexts where extreme oppression has led to mobilisation, they have a lot to contribute in terms of resistance and the ability to react. Despite sustained violence over almost two centuries, with different stages of land-grabbing and cultural obliteration, the Kaiowa have resisted and their population is on the rise. They represent an uncomfortable presence in the process of regional development based on agribusiness intensification and dominated by large private properties. The fact that indigenous groups even exist in the region, against all the odds, suggests that the socio-cultural landscape of Mato Grosso do Sul is much more complex than normally considered in reductionist analyses that reduce interactions to forces for or against development. In fact, the survival of the Kaiowa (and the other first nation groups in South America) reveals their remarkable strength and the astute strategies they have adopted (obviously, in no way detracting from their pain or minimising the significance of the long list of assassinations and attacks against them). There are elements in their culture and value system that are not easy to capture and bring to the realm of academic assessment, but it is not too difficult to understand that their cosmovision, their religious beliefs and practices, and their linguistic and artistic skills come together to form a coherent wisdom. As argued by the late Kaiowa leader Ambrósio Vilharba, retaking land is not the end in itself, but it "will reinforce our way of being Kaiowa" (in Markus 2013: 9). 
This sensitivity results from the accumulation of long-term collective engagement with the landscape, reaction or interaction with non-indigenous groups and the state, and the ability to incorporate and metabolise elements of the new world order. The tortuous, fragmented process of resistance and reaction is, essentially, a perennial attempt to project indigeneity into a space that is itself highly dynamic. The Kaiowa have had to struggle and wait, but - notwithstanding all the troubles and recurrent pain - they have kept alive the possibility (often translated into reality) of restoring spatial indigenisation. The irony is that this is ultimately an effort to re-indigenise a territory that used to be theirs.

A transformative indigenous research effort needs, therefore, to recognise the limitations of academic work (particularly in the present neoliberal context where universities are increasingly managed as businesses and academics are seen as money-making labourers) and dislocate the centre of knowledge production: knowledge is creatively produced on the ground, through an open, horizontal engagement between different voices in which the academic researcher is basically a facilitator, a translator of what has been jointly learned. Indigenous co-researchers should be able to have control over collecting information about themselves, to access and analyse information according to their own needs and goals, and to determine what should be communicated and how. At the same time, research practice must be planned to adequately comprehend, respond to and engage with social groups facing constant threats. Considering the context of violence and the willingness of the Kaiowa to pay a high human price in order to get their lands back, the research effort should be extremely careful to neither undermine ongoing mobilisations nor put people and leaders at risk (our visits to road encampments and retomada areas were certainly moments of high tension and apprehension for both the indigenous families and other research colleagues). This is not a trivial logistical question, given the recent history of the Kaiowa, marked by record numbers of murders and suicides. Likewise, there is a clear need to theorise the world from the perspective of the indigenous groups, rethinking universal concepts and searching for alternative socio-economic and political paths. Indigenous settings and cultures continue to require appropriate conceptual, methodological and interpretative approaches. Their contemporary condition is not only shaped by constant attacks and the pain of losing their land, but also by the resolve to resist and react, which will be analysed below.

\section{A frontier-making avalanche...}

Many readers are likely to have heard about the Guarani of South America in contexts including, for example, narratives about their striking architecture and a complex society managed by Jesuit priests located in the centre of the continent during the colonial period. Some may also be informed about the ongoing violence against the Kaiowa of the state of Mato Grosso do Sul (considered the Gaza Strip of Brazil). But few will be fully aware of the scale of land rights violations, systematic killing of adults and children, ferocious discrimination against people living in precarious roadside settlements or on the periphery of the cities, widespread suicides of young people and teenagers, and disturbing levels of insalubrity and food insecurity. The Kaiowa have been exposed to the worst side of frontier making, affected by land-grabbing, displaced from their ancestral lands and confined to minuscule reserves, and have experienced widespread socio-ecological exploitation (ranging from underpaid work to deforestation of their reserves for timber extraction). Kaiowa-Guarani life based on common land, managed by large families and regular movement around the region, has been (partly) substituted by the commodification of labour, land and nature, and, increasingly, by urbanisation, drug trafficking and cross-border contraband. 
There is actually no other way to describe the situation of the Kaiowa under the advance of soybean and sugarcane production (among other crops) than genocide, following Short's (2016) definition, which includes cultural destruction, social death and ecological devastation as equally important genocidal practices. ${ }^{2}$

It is crucial to observe that the advance of the economic frontier over indigenous land in Brazil was not only violent and disruptive, but primarily illegal. First and foremost, the Kaiowa have been the lawful owners of their land since colonial times and in accordance with the rules imposed on them. In 1680, a Royal Decree issued by the King of Portugal instituted the indigenato, which guaranteed that the concession of land to private individuals should not interfere with the 'original rights' of the indigenous groups to their land, as well as exempting the latter from any duty or tribute. This old legal principle that emanated from Portugal was gradually incorporated into Brazilian legislation, although in practice it was very easy to bypass the law and obtain land from the state or by employing widespread fraud (Vietta 2013). The legal system clearly guaranteed the rights of indigenous peoples and the protection of their cultural and material needs. Yet, after 1880, that did not prevent the concession of millions of hectares of Kaiowa-Guarani land to the Matte Larangeira company, a corporation that profited from the native mate herb (erva-mate) through the exploitation and even the scandalous, but tolerated, enslavement of indigenous populations. A few decades later, in the context of the paternalistic ideals promoted by Marshal Rondon, eight reserves were created between 1915 and 1928 (initially with 3,60o hectares each, later reduced following land grabbing by the surrounding farmers) by the newly established, and highly inefficient and corrupt, Indian Protection Service (SPI). This was a process of tacit 'containment' in small reserves, where indigenous peoples would be expected to be assimilated into the rest of national society (Brand 1997), similar to the policies implemented in the United States at the end of the nineteenth century. Because of the limited space and the agglomeration of different groups and families in very small areas, the reserves have been hotspots for tensions and growing frustration (CIMI 2001). The concentration of people facilitated the utilisation of badly paid indigenous labour, which guaranteed the economic insertion of the Kaiowa in the economy of the frontier and to some extent preserved their (highly subordinate) participation in regional society.

After 1920, large farms began to be opened by migrants attracted to the region from the south of Brazil and incentivised by the national government. A sequence of policies and legislation promoted the privatisation of ecosystems, deforestation and monoculture-based agribusiness. The region where most Kaiowa live in Mato Grosso do Sul is famous for its excellent red soils - the Kaiowa-Guarani affirm that the soil is red because it contains their own blood (see Morais 2017) - which were appropriated by the new farmers. Several migratory waves of people from Rio Grande do Sul (known as gaúchos) moved to Mato Grosso in the first decades of the twentieth century and then again in the 1950s and 196os, following the cancellation of the territorial concession granted to Matte Larangeira and increasing competition with erva-mate produced in Argentina (leading to the eventual closure of the Larangeira corporation). The Kaiowa were then coerced to leave their traditional lands and witnessed the destruction of the woodlands that give them their name ('people of the forest'). ${ }^{3}$ New legislation was introduced by the Brazilian military dictatorship in 1973 - the Indian Statute - but this basically maintained the assimilationist approach and failed to resolve the growing gap between the reserves that actually existed and the many other sites claimed by the Kaiowa as their legitimate land. A more recent phase began in the 1990s with the intensification of an agribusiness-based economy and the exponential

\footnotetext{
2 Much of the debate on the impacts and legacies of frontiers revolved around whether or not many indigenous groups were subjected to genocide and genocidal practices (Rogers and Bain 2016). However, van Krieken (2004) insists that the source of destruction may lie less in an "unambiguous 'intent to destroy' a human group, than in the presumption that there was not much to destroy," which means that the colonial settler ethos, although it may not spell out a clear plan for destruction, certainly provides ideational sponsorship for genocidal actions (quoted in Woolford and Thomas 2017: 71). Rather than focusing on legalistic notions of 'intent' by settlers and governments, it is essential to acknowledge the destructive potential of the systematic practices of cultural devaluation and social marginalisation. 
growth of plantation farms. Local changes directly reflected national trends and the power of the agribusiness sector, which included a broad coalition between landowners, conservative politicians, banks, industry and transnational corporations (Ioris 2018b). Agribusiness has been naturalised as above party disputes, a sector that is supposedly intrinsically beneficial to the country, meaning that any obstacle, including the rights of indigenous groups, must be removed, whatever the cost. In this sense, it has largely hijacked the political debate and forced the approval of highly questionable policies and legislation, as in the case of the new forest code, changes in labour regulation and the attraction of international investment funds (Ioris 2017). ${ }^{4}$

Brazilian agribusiness in agricultural frontier areas like Mato Grosso do Sul has given rise to even higher levels of speculation, dispossession of common land and wide-ranging aggression against those with different interests (Figure 2). Frontier making creates favourable conditions for the arrival of unscrupulous individuals in search of rapid enrichment and for the collective acceptance of morally questionable economic and political practices. The recipe for serious socio-spatial conflicts is then complete: on one side, adventurers and speculators reinvented as 'agri-food producers' (the euphemism often used by agribusiness farmers to describe themselves) and, on the other, marginalised native peoples who have been living in the region for many generations in a context of contrasting relations with land and society. The failure to meet indigenous peoples' legitimate demands and the invalidation of even their most basic human rights are clear signs of the institutional racism that pervades the Brazilian state and of how its ideology of modernisation has been constructed at the expense of, and against, subaltern sectors of society. Instead of legal rights over their land, the Kaiowa-Guarani have been offered only backdoor access to regional space, bearing in mind that since the early twentieth century farms have been opened in areas illegally expropriated by farmers and the government. The recurrent violence against the legitimate proprietors of the land - the indigenous groups - is in direct breach of the fundamental principles of the Brazilian constitution. However, enforcement of the legislation by local judges, civil servants and politicians typically rules in favour of the most powerful economic sectors. This corresponds to the wider problem of non-consensual expropriation of indigenous lands around the world (Doyle 2015).

Figure 2 - Agribusiness production in Mato Grosso do Sul in areas grabbed from the Kaiowa-Guarani

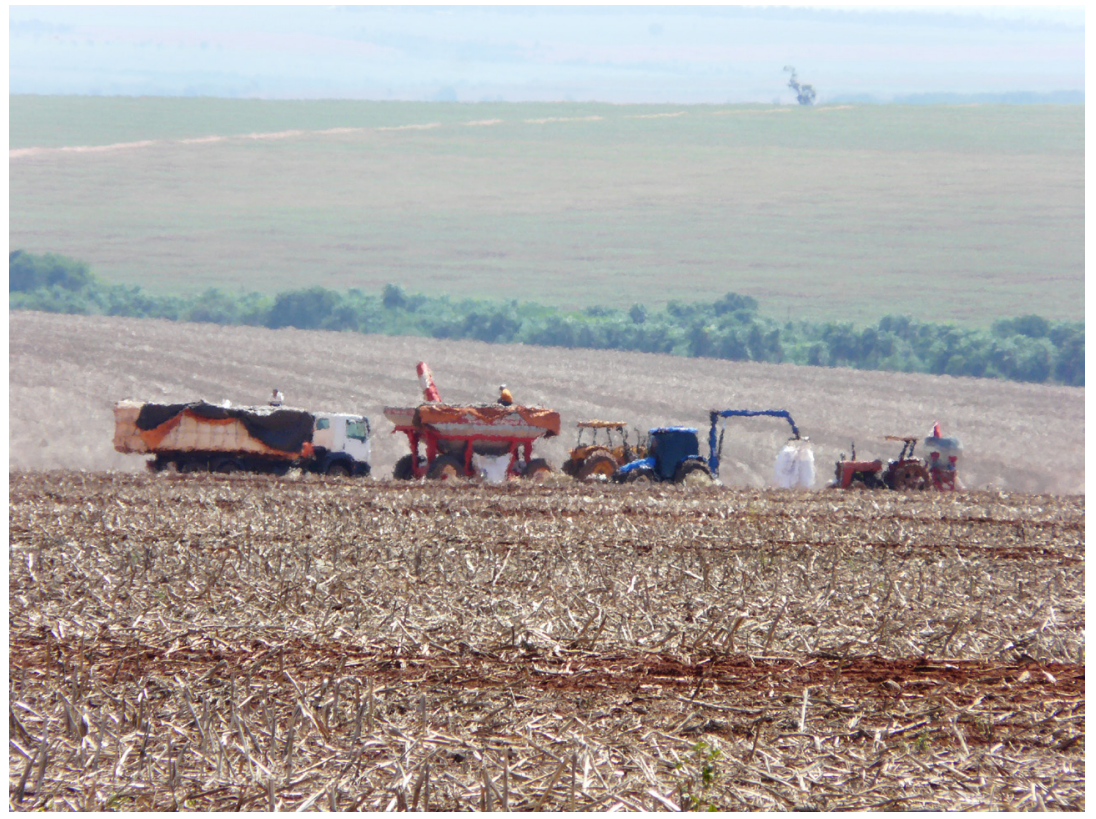

(all pictures by the author)

4 The 'bonfire' and destruction of the National Museum of Rio de Janeiro on 2 September 2018 offered a sinister metaphor for the low quality of Brazilian democracy and the neglect of public culture and social justice. Likewise, the pervasive violence against indigenous groups was graphically reproduced on 21 April 2000, on the very site where the Portuguese arrived in the country, during the commemoration of five centuries of Brazilian history. 
The dominant ideology of a 'timeless Indian' (i.e. idealised, according to the colonial mindset criticised above, as a savage who, to be genuine, has to be confined to the past, a depiction permeating school textbooks and the public imaginary) gives support to the idea of an 'spaceless Indian' (no rights over land, no need for land, no space) because they have lost their right to land insofar as they are no longer seen as 'real Indians.' This is an example of the 'tyranny of authenticity' that threatens to exclude individuals and groups who do not fit the narrow criteria set for membership (Lennox and Short 2016). The Kaiowa have been subjected to a persistent, everyday experience of social, ecological, cultural and physical violence, and seeing their rights recognised has been a difficult struggle. During the first visit of Pope John Paul II to Brazil, the Guarani leader Marçal de Souza Tupã-Y denounced the long-standing practice of expropriating land and massacring indigenous peoples, demonstrated by Figure 3. After several unsuccessful attempts by farmers to bribe and quieten Marçal, he was murdered on 25 November 1983, three years after meeting the pope. As has so often been the case, nobody was held responsible or punished for Marçal's murder. In fact, public agencies are often driven to provide some kind of response only after a large-scale tragedy is reported by the international media. The bad news has kept pouring in: "High murder rates blight Brazil's indigenous communities" (BBC 28 February 2014); "Brazil indigenous leader's killing raises tension" (BBC 3 September 2015); "Dispute turns deadly as indigenous Brazilians try to 'retake' ancestral land” (The Guardian 14 July 2016); “The Guaraní Kaiowà people could soon be wiped out" (Lifegate 20 April 2017); “Au Brésil, une manifestation d’Indiens tourne à l'affrontement avec la police" (Le Monde 26 April 2017). The New York Times reported on 29 May 2017 that in "August 2015, some of the Guarani-Kaiowa decided to reoccupy part of their territory. They camped on land owned by ranchers. The landholders had other plans: according to reports, they hired armed militias to try to drive the tribe out. Semião Vilhalva, a tribal leader, was shot and killed. There were accounts of torture, rape and child abduction."

Figure 3 - Graves of indigenous people killed by farmers in Caarapó

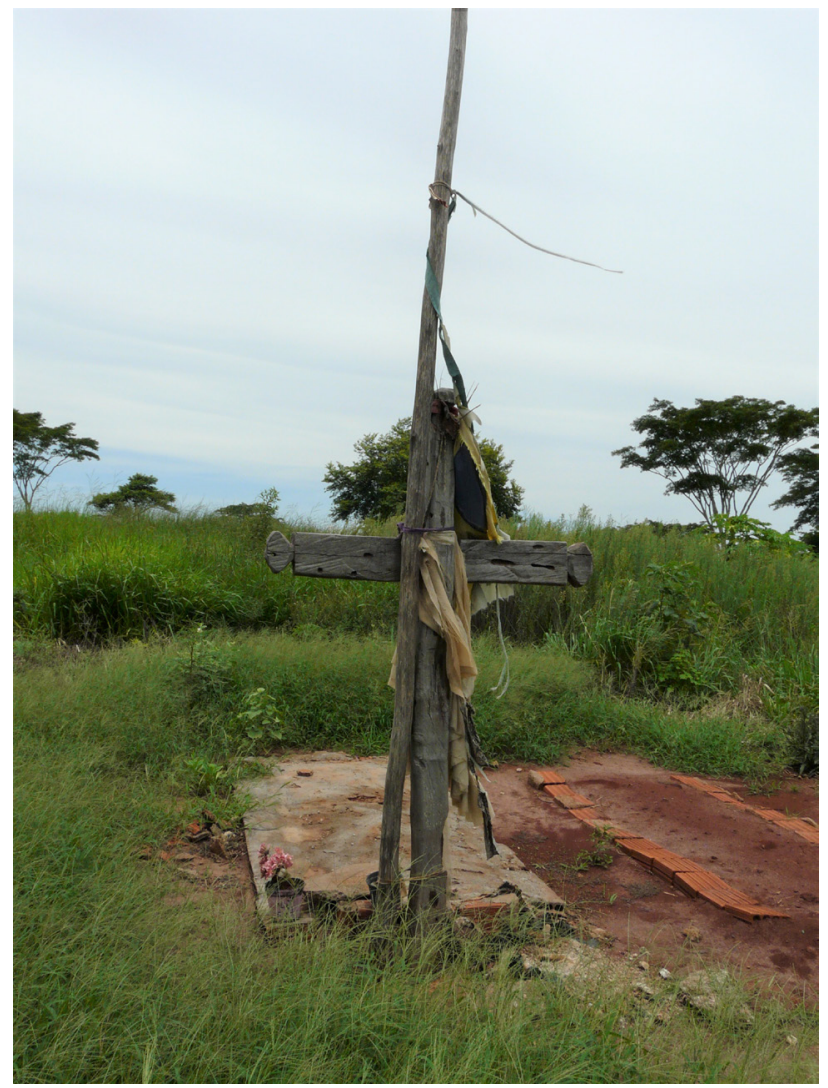


Another famous victim was Ambrósio Vilhalba, a leader of the Guyra Roka ('Place of the Bird') community, who had spent decades campaigning against the planting of sugar cane on his tribal lands. He became internationally famous after taking part, as the main character, in the award-winning film Birdwatchers (sadly and prophetically, the character was based on himself and, as in the movie, he also ended up being murdered). He travelled the world to speak about the Brazilian government's failure to protect native Guarani land. After months of death threats, in 2013 Ambrósio was found dead in his hut from multiple stab wounds. According to Guarani religious beliefs, death by murder or suicide is not the end of the story but brings additional troubles to all those involved. The Kaiowa feel particularly demoralised when, as happens quite often, a relative is murdered and the body simply disappears (Morais 2017). Violent deaths without a body to bury are considered to be very dangerous, given that a person has two souls and the bad one [angue] will linger on like a phantom, threatening the living. Caught up in a hyper-violent situation that affects both the dead and the living - further aggravated by the election in October 2018 of a right-wing president, which immediately triggered new waves of attacks on indigenous groups and many other racial minorities (as reported by Fuhrmann 2018) - the Kaiowa-Guarani have responded according to their means and have formed some limited but important alliances with national and international organisations, universities and churches. They have, therefore, disrupted the pace and the configuration of frontier making, leading to a mosaic of spaces, as discussed next.

\section{... but an insurgent indigenous geography}

The Kaiowa-Guarani, along with countless other indigenous peoples in South America, had their territories invaded and socio-cultural practices disrupted as part of the wider process of frontier making. The sociospatial frontier enveloped them like an avalanche and triggered a long process of aggression, intolerance and forced assimilation. The 'Kaiowa problem' - more accurately, the problem brought to the Kaiowa and their forced conversion into a problem (Ribeiro 2015) - has been an acute process of commodification (in the nineteenth century of forests and labour, and in the twentieth century of land, labour and water), facilitated by the production of racialised spaces that marginalised indigenous populations in their own territory. While the Kaiowa were historically at the margins of official national history, frontier making left them even more ostracised and oppressed than during the colonial years. Out of the four million hectares originally occupied by the Kaiowa in the region, indigenous families were left with around 40,0oo hectares of regularised land, spread across various reserves and resettlements (Benites 2014; Brand 1998; Cavalcante 2014). Some reserves are extremely small (only a few hectares per family, or even less, as in the case of the Dourados reserve, where 15,00o people live on just 3,00o hectares) and land tenure is not clear because of objections from farmers and other business sectors (even after the lengthy process of regularisation). Despite all this, the Kaiowa have demonstrated an unfailing ability to adapt to the new world order and to retain crucial elements of their identity, culture and knowledge, certainly of help to them in their struggle for land and recognition. Combining multiple strategies, which have included settling in remote corners of the large farms, seeking employment outside the reserves, making their voices heard in public and forming strong internal and external networks, the Kaiowa have managed to engage with the advancing frontier and, in recent years, secured some modest but nonetheless tangible political and territorial successes. 
Through the mobilisation of their customs and religious values, the Kaiowa-Guarani have vividly replicated, in accordance with their own circumstances and way of life - what they call ava reko - shared elements of the social and agrarian transformation that has been taking place around the world over the last few centuries of capitalist history. ${ }^{5}$ It is a dynamic geography of general similarities or commonalities, but also with distinctive cultural and politico-ecological characteristics. Kaiowa existence is particularly differentiated by a scalar and deeply religious conception of space, extending outward from the household to the network of settlements and indigenous reserves. Following the Kaiowa cosmovision, people do not own or trade the land, but live there, sharing it with other creatures and constantly having to negotiate their conditions. These creatures hold or belong to the spirits (jaras), whose categorisation depends on the relations established between humans and non-humans (Pereira 2010). These religious, cultural and social experiences are constantly mobilised in favour of their daily survival and, in cases of dispossession, the prospect of returning to the lost areas. The skilled resistance of indigenous groups demonstrates both the inadequacies of the modernising project and the resilience of non-Western societies when protecting livelihoods and cultural practices on their land. In this way, Kaiowa groups have become one the most active geographical protagonists in the region, constantly trying to adapt and respond to pressures, as well as protect and restore elements of their previous life conditions disrupted by frontier making. This is materialised in the diversity of spaces through which the Kaiowa subvert and complicate the course of frontier making, as described below.

Indigenous reserves - despite serious management problems, reserves constitute the most stable spaces available to the Kaiowa, largely accepted by wider society and reasonably well protected by the state. The reserves were established in two main phases. The first involved the creation of the eight SPI reserves, totalling around 18 ,ooo hectares, in the first decades of the 20 th century. The process imposed the 'peasant model' on the Kaiowa, fixing them in certain state-owned areas where the land can be cultivated by the community (Oliveira 1983). This was certainly not a stress-free process, given that not all the reserves were established in the areas where indigenous families originally lived, but were merely determined by bureaucratic convenience (most of these first reserves even had their area reduced due to pressure from neighbouring farmers, assisted by corrupt civil servants). Against the will and the traditions of the indigenous people, the land in the reserves was divided into private lots, a practice in direct conflict with their tradition of common land (tekohakuaah) (see Figure 4). One very serious issue was the accommodation of different extended families or ethnic groups (Kaiowa-Guarani, Nhandeva-Guarani and Terena) in the same reserve, which only generates new tensions and nurtures disputes. Levels of violence and crime in the reserves are directly or indirectly related to growing frustration with persistent abandonment, racism and discrimination. Stories about youth violence in the reserves are favourites in the local and national media, particularly those involving sexual assaults, gang killings and drug trafficking.

\footnotetext{
5 The eighteenth-century English experience is a case in point, described by Thompson (1993), where enclosure took the commons away and made people strangers in their own land. At the same time, the appropriation of common land and the reduction of food security in England triggered riots, which were the rational response of poor people with some remaining power to help themselves.
} 
Figure 4 - Indigenous family household in the Pirajuí Reserve

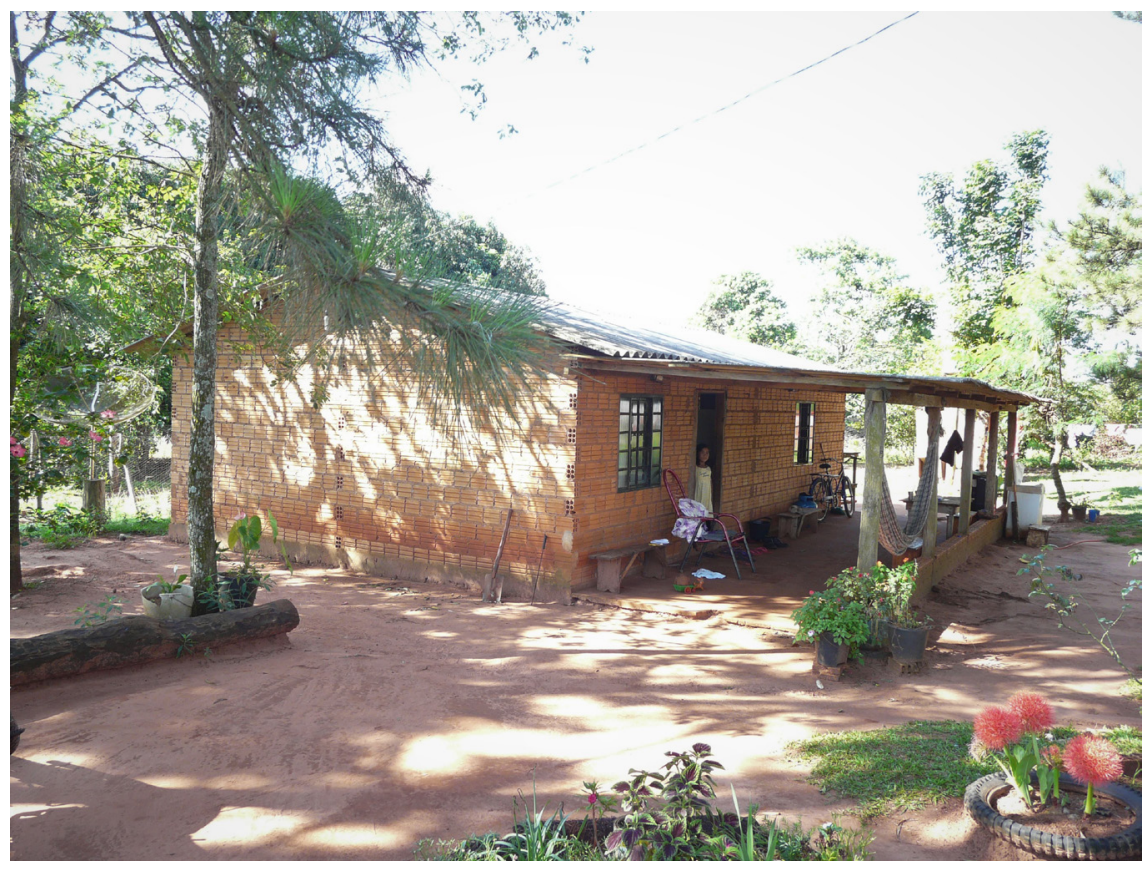

The second phase of reserve formation was launched by the approval of a new Brazilian constitution in 1988, which officially recognised indigenous lands (Article 231) as areas traditionally and permanently occupied by indigenous peoples and indispensable to their productive activities, to the preservation of environmental resources needed for their well-being, and to their physical and cultural reproduction in terms of uses, customs and traditions. The same constitutional article determines the nullification of any act that led to the occupation or appropriation of indigenous lands, stating that these are inalienable and the rights over them imprescriptible. Approval of the new constitution coincided with the adoption of the Indigenous and Tribal Peoples Convention (ILO-Convention 169) in 1989 and the growing international importance of the principle of 'free prior and informed consent' (FPIC). The problem for the Kaiowa-Guarani has been the lack of enforcement of these formal rights and their refusal to consent to the confiscation of their lands. A protracted struggle invariably unfolds through the various layers of the judiciary, with endless appeals and explicit political pressure exerted on local judges (normally themselves large landowners and members of wealthy regional families). Among the 51 existing reserves, only 24 are reasonably stable, although this does not mean they are free from tensions (Zelic 2018). Policy failures and still unmet demands are rationalised by politicians and authorities on the grounds as an outcome of the need to follow due process, but really they benefit the agribusiness sector and reflect the social need to accept the costs of development (as so often, the victims are blamed for their own misfortune).

Roadside encampments - Because of organisational, behavioural and demographic problems in the official reserves, a significant proportion of the Kaiowa-Guarani people - around a quarter of the total population - have opted to move out and live in encampments next to the main highways and secondary roads. These encampments may be relatively permanent sites of residence (there are cases of families who have stayed in such dreadful conditions for many decades) or temporary campsites for families hoping to move back to reclaimed areas (retomadas). In both cases, though, people living in encampments maintain close connections with relatives in other sites and in the reserves, always with the expectation of better conditions and the hope to return to the areas where they or their families used to live. The Kaiowa have resolutely resisted the antagonistic rationality that led to this fragmentation and privatisation of space, closely promoted and 
coordinated by the Brazilian state (Barbosa and Mura 2011). The space of the encampment, regardless of the unpleasant and insalubrious circumstances, is also a space of anticipation and potentiality. This ambivalent situation, among other aspects, is presented in the documentary film Martírio by Vincent Carelli, released in 2017, which shows how precarious and risky the conditions are for the Kaiowa, but also reveals their firm commitment to survive and honour their ancestors. A constant threat is posed by farmers and paramilitaries (as mentioned earlier, militias hired by farmers and rural companies, normally employing retired or active policemen). There are also the serious risks of road traffic accidents and wildfires spreading from sugarcane fields ahead of the harvest. Despite recurrent cases of violence, the police express little interest in finding those responsible for the crimes, and the judicial system is quite unprepared to punish. These forms of treatment only fuel resentment and, paradoxically, lead more individuals to join roadside encampments ahead of future retomadas.

Areas of Retomada - literally, retomada means 'taking back,' but more significantly it implies reaction and spatial re-occupation (social movements in Brazil reject the politically derogatory term 'invasion'). The retomada is the return to the original places from which the older Kaiowa generations were expelled in the 1950 or 1960 (many elders are still alive and able to testify to their connection with the sites in question). Through the retomadas, "indigenous families reoccupy areas where they can carry out their community life, establishing their dwellings, planting smallholdings, and practicing their ritual and religious life" (Oliveira 2018: 12). The retomada is a political expedient of peasant-like resistance that relies on the construction of material, organisational and ideological means for its utilisation (Ferreira 2007). In Guarani, retomada is described as jeike jey (jeike comprises the verb 'enter' modulated by a reflexive prefix, here translating as 'we enter' or 'let's enter' [we inclusive], while jey means 'again'; thus jeike jey literally signifies 'we enter again,' which may be translated as return or retomada). After a frustrating wait and exasperation over unfulfilled promises, indigenous political and religious leaders realised that the official approach to creating reserves was misleading and would never address their economic and cultural needs. These leaders (invariably, obvious targets for new assassinations) organised a group to take action and evict the actual invaders - the current farmers - and attempt to self-demarcate their legitimate lands. Retomadas are moments of rupture, when dominant politics is subverted and indigeneity can emerge through "an insurgence of indigenous forces and practices with the capacity to significantly disrupt prevalent political formations" that render "illegitimate the exclusion of indigenous practices from nation-state institutions" (de la Cadena 2010: 336).

The fundamental difference between the original SPI reserves and retomada areas is that the operationalisation and risks involved in these initiatives are assumed exclusively by the indigenous groups, outside the tutelage of the state (see Figures 5, 6 and 7). "Given the nonexistence of other efficient alternatives, the retakings [retomadas] have turned into the main strategy of indigenous people for recognition of their territorial rights, at present, having been incorporated as a flag of struggle by the indigenous movement... They constitute a post-tutelary form of the exercise of the policy by the Indians, implying a different mode of conceiving their relationship with the State" (Oliveira 2018: 13). CIMI has registered at least 88 areas demanded by the Kaiowa-Guarani, but the list is certainly much longer (Morais 2017) and the struggle now is to recover areas much larger than the old reserves (retomadas from farmers with more than 10,00o hectares), which of course infuriates the agribusiness community and allied judges and politicians. It is crucial to note that this autonomous movement is more than just a form of indigenous agrarian reform: it expands into an intense site of spatiogenesis where traditions, new influences and articulation with other sites and other groups converge to consolidate the newly retaken land. Ethnographic work has revealed that the retomadas "imply deep movements of cultural revitalisation and social and political reconfiguration for these peoples" (Oliveira 2018: 14). 
Figure 5 - Retomada in the vicinity of the Dourados Reserve

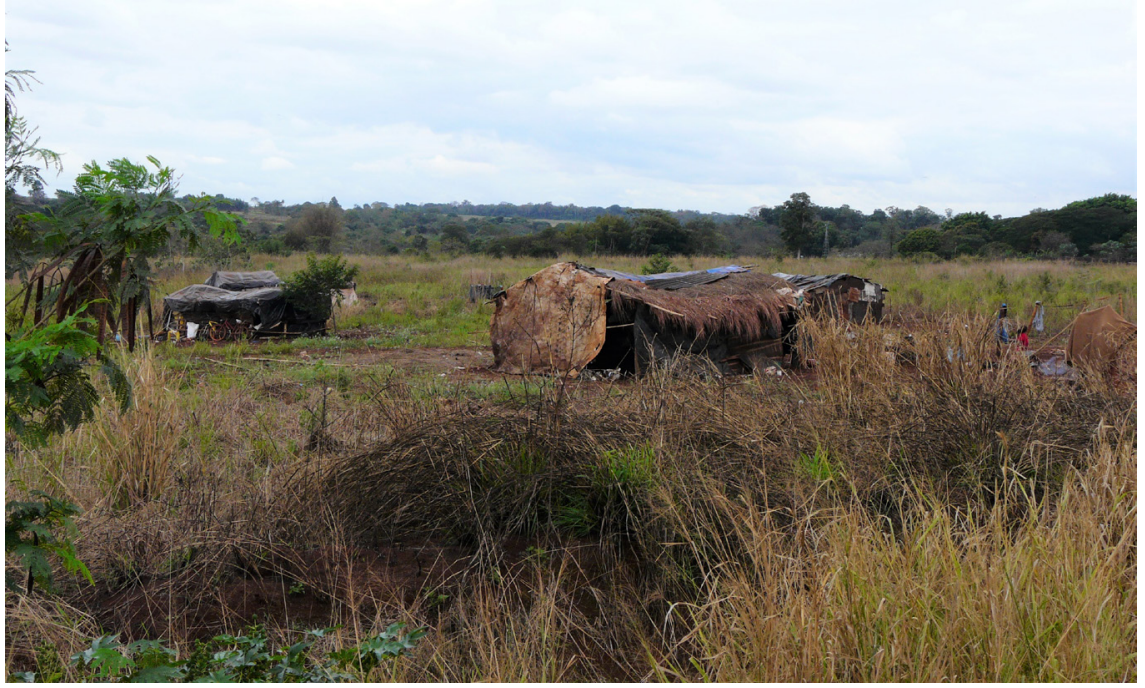

Figure 6 - Private security guards (paramilitaries) hired by farmers to contain a retomada

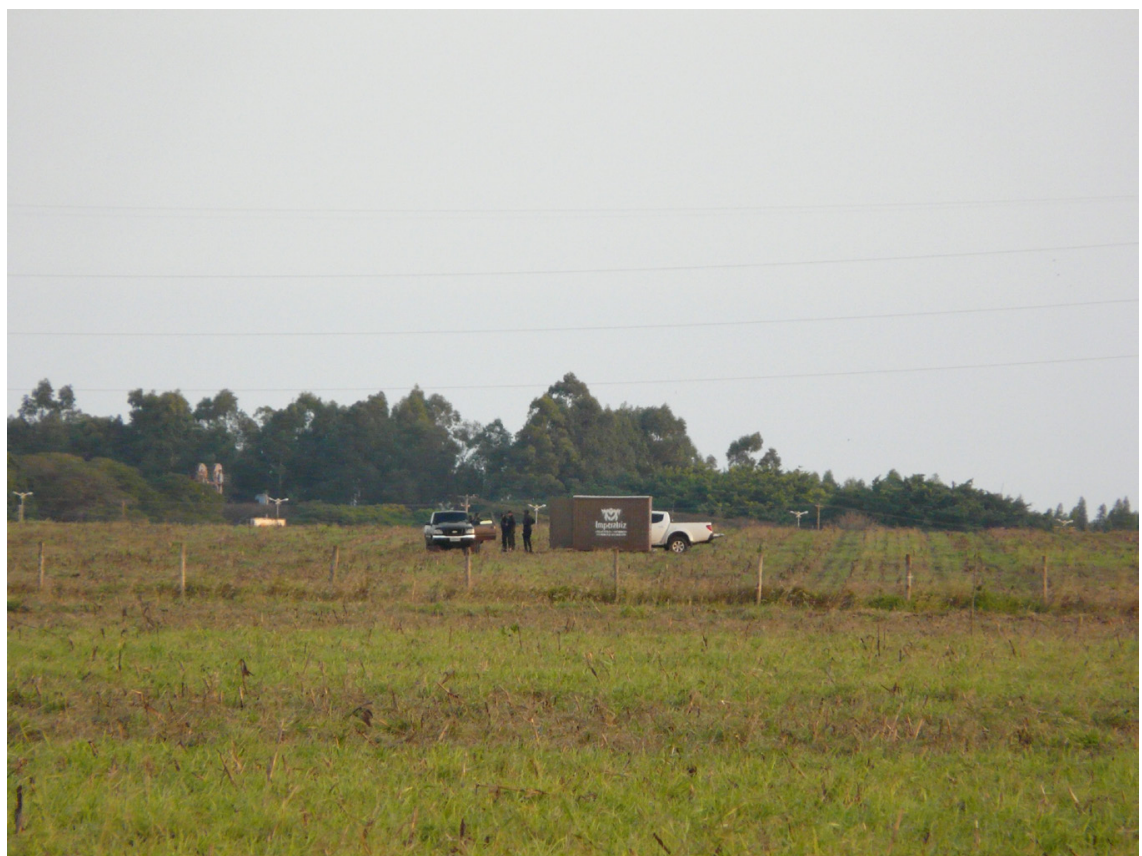


Figure 7 - Indigenous family in a retomada on a soybean farm in Caarapó

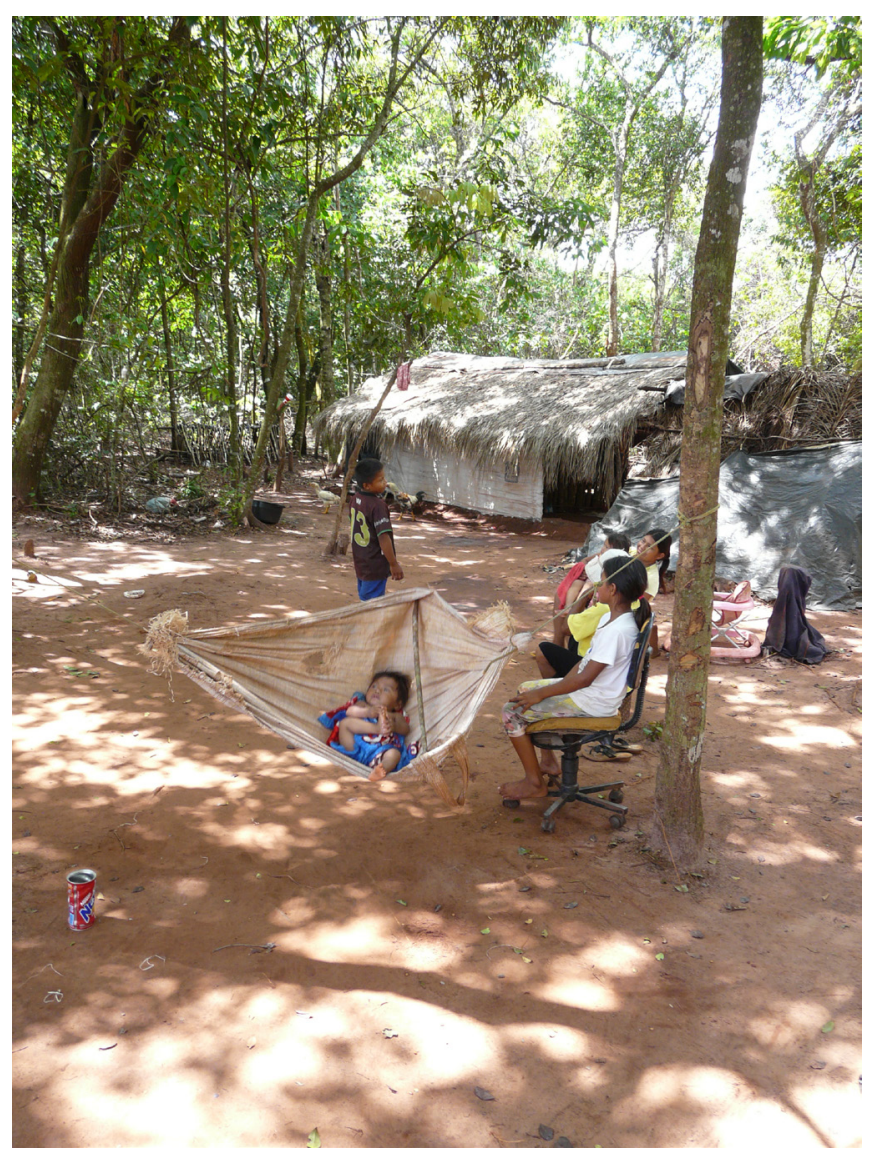

Globalised Kaiowa space - another important space competently produced by the Kaiowa as part of their political agenda of survival and territorial affirmation is an international arena of protest, involving a network that includes academics, artists and multilateral organisations. In the last few years, various Kaiowa leaders have been interviewed by global media channels, invited to speak in international forums and taken part in publications, movies and documentaries. The insertion of the Kaiowa in globalised space is evidently related to broader indigenous movements around the world (see Lennox and Short 2016). All of this has attracted growing attention from the international community, enabling the movement to be compared with prominent campaigns articulated by other ethnic and cultural minorities. The activism of the Kaiowa in national and international circles shows that their leaders have realised the importance of employing an effective, articulate discourse and learning to engage with non-indigenous players. Public outrage over the Kaiowa genocide has soared across the world and triggered multiple reactions. On 24 November 2016, the European Parliament approved a resolution strongly condemning "the violence perpetrated against the indigenous communities of Brazil," deploring "the poverty and human rights situation of the Guarani-Kaiowa population in Mato Grosso do Sul," reminding "the Brazilian authorities of their obligation to observe international human rights standards with respect to indigenous peoples" and, among other things, expressing "concern about the proposed constitutional amendment 215/2000 (PEC 215), to which Brazilian indigenous peoples are fiercely opposed, given that, if approved, it will threaten indigenous land rights by making it possible for anti-Indian interests related to the agrobusiness, timber, mining and energy industries to block the new indigenous territories from being recognised.”

6 Those worries attracted another resolution by the European Parliament, approved on 3 July 2018, against the violation of the rights of indigenous peoples, including the impacts of land grabbing. 
PEC 215 is essentially a canny manoeuvre by the Brazilian parliament to stop the creation of new indigenous reserves (which would become an exclusive prerogative of the agribusiness-dominated congress). ${ }^{7}$ This would have terrible consequences for most Kaiowa who have been forced from their ancestral lands.

Spectral space - the Kaiowa-Guarani cultural background contrasts with the rigid, artificial limits of private property institutions, which constrain social mobility and interfere with traditional agricultural practices based on the rotation of cultivation sites. According to Kaiowa-Guarani traditions, the space required for a family needs to be constantly regenerated and reconfigured by a movement through the landscape that is essential for the fulfilment of their way of life. The consequences of land commodification and the advance of the agribusiness frontier were thus extremely negative for these indigenous groups. Even so, in a way that was unanticipated by governments and farmers, the Kaiowa have resisted and recaptured some tracts of land, and their population is on the rise. They have represented an uncomfortable presence in the regional economy and a nuisance from the perspective of local elites - a threat constantly present in the Guarani names for places and things and the alarming presence of 'these strange people' in roadside encampments who, from time to time, come together to demand another area they associate with their heritage. Their leaders have repeatedly emphasised that their long-term, non-negotiable goal is to reinstate most of the original Kaiowa territory, instead of the small islands granted to them so far by the state (Barbosa and Mura 2011). The political crux of the matter is that the land demanded by the Kaiowa is legitimately theirs not only because indigenous populations used to live in these areas (which is the main legal stipulation for the return of ancestral land) but, more importantly, because the possibility of a meaningful future for them fundamentally depends on their physical and metaphysical interdependencies with this land. In other words, the Kaiowa, just like other subaltern and proletarian groups, are politically relevant not because of their past, but because of their future based on anticipated ownership of the land (as Figure 8 shows, the Kaiowa reject the current spatial configuration and use road signs to affirm ownership and the right to name their own land).

Figure 8 -Indigenous name of the land painted over farm signposts

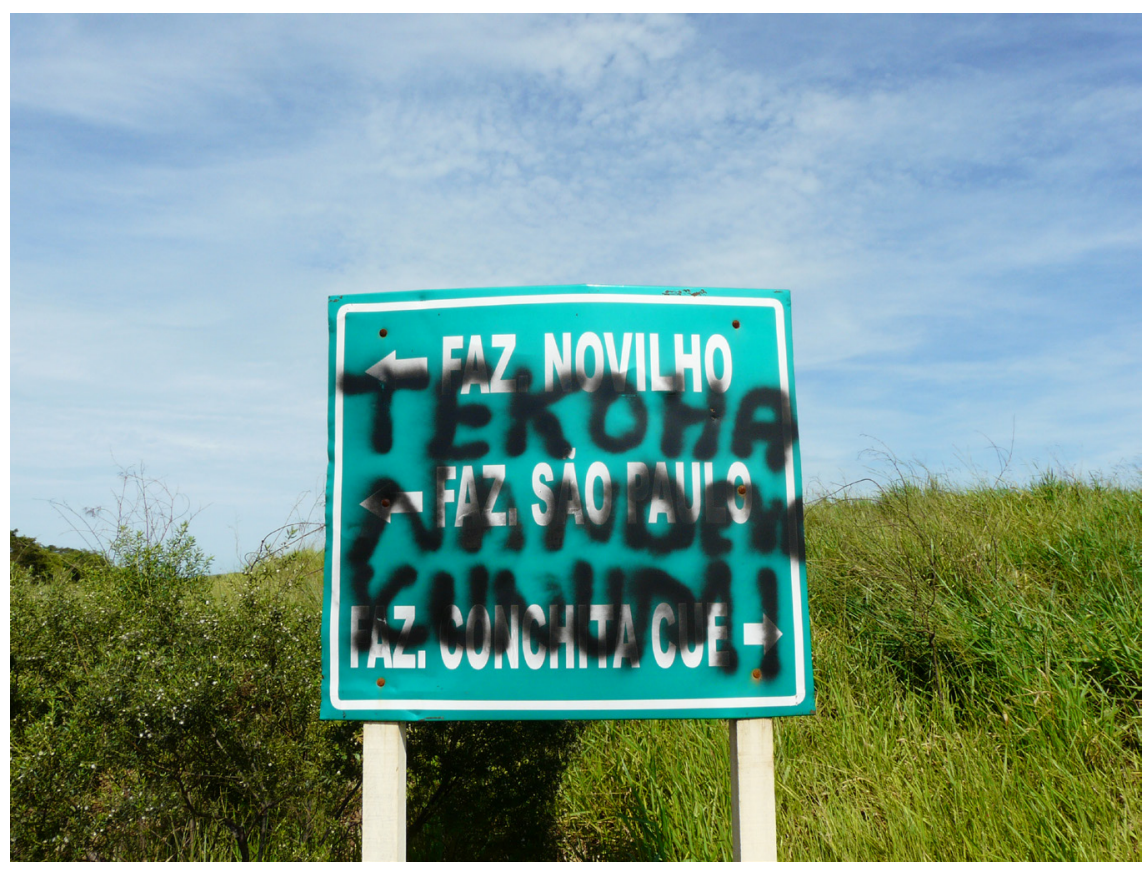

\footnotetext{
7 Another extremely controversial measure, adopted by the Supreme Federal Court and now under analysis in the same parliament, is the marco temporal (arbitrary cut-off date for land claims). The intention is to restrict the legal right for claiming traditional territories to land physically occupied on 5 October 1988 (the date of approval of Brazil's current constitution).
} 
Kaiowa geography evolves in different directions and contains multitemporal elements from their past that shape the visible present and the desired future. A crucial part of this geography is the large 'space in waiting' that is dreamt about, constantly narrated and re-narrated for younger generations, an anticipation of a concrete future reality that will reinstate the past. It constitutes the spectre of a lost world that nonetheless will be restored one day if they continue to actively envisage it. The distribution of the existing reserves on the map shows this palpable spectre (the vast land in between reserves and encampments), a constant reminder of the perennial defiance and forthcoming action of the Kaiowa to recover land that is theirs. ${ }^{8}$ Their spectral condition is a shameful sign of the misplacement of things and, to the frustration of politicians and farmers, they have national law and universal human rights in their favour, although still poorly enforced. They have the moral high ground of those who were brutally invaded and subjugated for spurious material gain. Nowhere does the Kaiowa spectre cause more anxiety and theatrical vociferation than in the Brazilian House of Representatives, notoriously dominated by agribusiness interests. Congressional members of the Parliamentary Farming and Cattle Raising Front (Frente Parlamentar da Agropecuária), in particular, like to put on a show in front of the cameras to impress voters and supporters. The 'Indian problem' is a juicy topic, able to mobilise parliamentarians from different parts of the country, and in this context the Kaiowa-Guarani represent the most combative threat and a 'bad example.' For instance, in a public audience of the Agricultural Commission held on 8 May 2013, with the presence of several Secretaries of State, to discuss growing demands for the rehabilitation of indigenous areas (the main focus was on Mato Grosso do Sul), some of the more vociferous congressmen spoke as follows:

Is the Government's goal for $25 \%$ of Brazilian territory to be indigenous areas? I have seen a FUNAI ${ }^{9}$ report saying that the aim is for $25 \%$ of Brazilian territory to be indigenous areas. It says that there are 611 areas due to be created as indigenous lands [...] A new indigenous Guarani nation is about to be born. (Valdir Colatto)

There was no solution, and the problems were getting worse [...] We are seeing, in this process, orchestration, abuses, the pressure that the Indians make [...] [The Indians] leave their land to create other reserves [...] If we do not take action, they will be creating Yanomami, Guarani, and other nations. And they have the support of the King of Norway, who funds NGOs [...] I am of German origin - my ancestors came from Germany in 1853 - but I am Brazilian, I defend this country and I will defend it intransigently. We cannot give in to this pressure... (Luis Heinze)

In Mato Grosso do Sul, we have had numerous invasions of rural properties, with the support of FUNAI, to where Indians are taken, clearly with documents from Paraguay. (Reinaldo Azambuja)

Leaving aside the poor syntax of the strident politicians, the acrimonious, racist and bitter speech suggests that the establishment is on the defensive and, at the very least, deeply disturbed by the indigenous peoples' moral and legal upper hand. Hegemonic groups and their political representatives are less in control than they would like. This meeting of the Agricultural Commission was organised a few days after a flamboyant invasion, in the middle of a plenary session, by dozens of indigenous leaders (17 April 2013) in protest against PEC 215 (see above). Dialogue seems quite impossible (as Marx put it, "force is the arbiter"), even more so in a National Congress where a significant proportion of members - who also own large farms and are often involved in massive corruption scandals - sponsor a clear anti-indigenous agenda.

\footnotetext{
8 This can be consulted at https://terrasindigenas.org.br

9 FUNAI (the National Indian Foundation) is the government body that deals with policies relating to indigenous peoples. In 2019, it was removed from the Ministry of Justice and became part of the Ministry of Human Rights, while responsibility for the demarcation of indigenous areas was transferred to the Ministry of Agriculture (controlled by the agribusiness sector and openly against the recognition of indigenous land rights). The minister appointed by the new president in January 2019, Ms Tereza Cristina, is a large-scale farmer and a congresswoman representing Southern Mato Grosso, who selected as close advisors a team of lawyers who had fiercely attacked the Kaiowa-Guarani on behalf of landowners.
} 
Numerous bills have been introduced aiming to erode legislation on the regularisation of indigenous areas, while deepening the commodification of labour and nature has been a top priority in recent times in Brasilia (CIMI 2018b). This reinforces the paradoxical situation that those who are ostensibly vulnerable and powerless are clearly able to alarm those who are nominally powerful, but who have fundamentally abused their mandate and turned their back on justice and democracy.

\title{
Reconstruction of the Kaiowa space
}

\author{
Morirò... ma invendicato \\ il mio nome non sarà, \\ il mio sangue avvelenato \\ mille morti costerà! \\ Pery, in the opera Il Guarany, by Carlos Gomes (1870)
}

The Kaiowa, despite their troubles and the abject violence they have experienced, have written one of the most intriguing stories of contemporary, multicultural Brazilian society and its perennial dependence on frontier activity. It is a situation fraught with tensions and hidden complexities. From the perspective of indigenous groups, frontier making is a process of hyperbolical action that generates its own antipode, as movement in one direction often ultimately leads to opposite results..$^{10}$ The Kaiowa-Guarani have had to resist an antagonistic rationality that has invariably led to the fragmentation and privatisation of space, promoted and coordinated by the national state. There has been a terrible banalisation of aggression, regular assassinations, and most of their ancestral land is still a spectre, which seems to prove that the Kaiowa are merely on the losing side of regional development. Their land was grabbed, their social life violently disrupted, their world will never be the same. Yet, the experience of frontier making endured by the Kaiowa demonstrates that indigenous groups are, in effect, both victims and protagonists. The very presence of indigenous peoples in the region, after decades of abuse, reveals a remarkable capacity to cope, despite all the difficulties, with the negative impacts of the advancing frontier and suggests that such groups are among the most resilient and skilled of those embroiled in frontier making. It is true that the impacts of colonisation affected the Guarani groups later than the majority of other indigenous peoples (for a number of historical reasons, including the Jesuit missions and their hiding in the forests), but it is also the case that their recent history has been marked by extraordinary courage in handling market-based globalisation, the commodification of common resources and the homogenisation of culture.

Indigenous peoples have commonly been portrayed in mainstream Brazilian political debate using normative language which represents them as responsible for their own condition. In this way, their action has been judged against criteria and values that are foreign to them. This is an ex post facto construction of their fate that leads to further misunderstandings. Many of the subtle elements in their culture and value system are not easy to bring into the realm of westernised academic comprehension, but it is not too difficult to perceive a wealth of sensibilities that help to fill many of the social and ethical gaps of frontier making. The Kaiowa have a fundamentally different association with the landscape where their ancestors were buried and still are, given that, for them, both the living and the dead reside in this land, their life, identity and existence depend on this land, and at the end of their life they themselves become land. Areas beyond the farm fences are remembered, evoked, celebrated and, when the time is ripe, claimed and ultimately recovered. What is regularly missed in conventional accounts is the truly latent geographical agency of the Kaiowa: that is,

10 In the words of Galeano (1982: 63), "Colón, buscando el Levante, ha encontrado el Poniente. Leonardo adivina que el mundo ha crecido" (Columbus, looking for the Levant, has found the West. Leonardo guesses that the world has grown). 
their ability and willingness to remember and dream of a different spatial setting, organised according to their own culture, values and knowledge. After the humanist lessons of Yi-Fu-Tuan, we know that geographical agency not only includes physical action, but also possesses a crucial subjective and symbolic dimension. The geographical agency of the Kaiowa - which is basically an expression of a political ontology - is translated into a landscape of potentialities in which the indigenous groups struggle to survive in the interstices of agribusiness modernisation and constantly nurture their preparations for a different spatial reality erected on the basis of a lived cultural heritage.

The recognition of such latent agency unveils the tripartite ontological configuration described by Deleuze (1968) at the intersection of the interdependent 'registers' of the virtual, intense and actual. According to Deleuze, intensive morphogenetic processes follow virtual multiplicities to produce localised, actual realities with extensive properties. Unlike how it is normally described, the political power of the Kaiowa is maintained independently of their immediate control of the territory, accumulated instead as a latent geographic agency eventually manifested in the retomadas. The virtual is actualised by way of intensive processes. Because of their geographical agency, the Kaiowa-Guarani have managed not only to recuperate their religious traditions, but to mobilise these in support of their social identity, political voice and spatial strategies. Their search for a better life is informed by the symbolism of a mythic land of peace and plenty. Different Guarani groups have distinct myths and narratives of the 'land without evil,' but for the Kaiowa the myth is certainly a source of hope and helps them in the difficult journey back to the lost areas (Chamorro 2010). Notwithstanding the many profound changes and influences that have affected the Guarani, their most cherished religious and existential creeds continue to underpin social values and interpersonal relations. According to Clastres (1975), the search for the new world has been pursued for centuries through physical movement across the South American territory, led by powerful spiritual leaders to overcome existing circumstances and socio-political crises. In this sense, the religiosity that infuses Guarani cosmology operates as a refuge and has left them prepared to cope with contemporary economic frontiers. Against all the odds, the Kaiowa-Guarani have revealed a deep persistence and wisdom in using their ancient religious beliefs to help them deal with twenty-first century challenges.

The theological thought of the Kaiowa corresponds to a particular time-space conceptualisation of the world in which deities enter terrestrial households and establish relationships (Mura 2006). The main locus of geographical agency is the interface between the extended family (with around 100 individuals) and the larger indigenous network that connects different reserves and settlements. The basic spatial unit is the tekoha, the specific area where one or a few extended families live, strongly connected with other tekohas through regular meetings, marriages and ceremonies. A tekoha has no rigid limits, but comprises the space needed to hunt and fish. It is broadly delimited by hills and rivers, and often includes a river basin (Benites 2014). Its meaningcontent has more to do with the production of culture than with economic production (Meliá 1989 apud Brand 1998: 23). According to the Kaiowa-Guarani tradition, when there is a disagreement or need for more resources, part of the group moves to another area and establishes a new tekoha (Silva 2007). Spatial mobility (guata, which means wandering around, walking or perambulation) is thus a key vector of Kaiowa-Guarani culture and essential to maintaining a good way of life (Brand 1998). The movement associated with guata suggests a constant willingness to be free to resettle elsewhere in order to maintain the livelihood of the family and to guarantee social reproduction. Guata also enables contact with tekohas lost to economic development and fosters a perennial longing for return to such areas that still show marks of indigenous activity from decades ago (burial grounds, old settlements, cultivation plots, etc.).

According to Kaiowa religiosity, these lost areas remain populated by gods and invisible entities, some benign, some evil, so people must prepare themselves spiritually before they can return. The radicalism of indigenous spatial action (incomprehensible for the rest of society and apparently illogical, considering the level of killing and suffering they have experienced) is guided and anchored by the invisible world of their 
ancestors and the dream of a land that will restore the desired connections between the gods, the dead and the present generations. The latent geographical agency - a true geography of potentialities - is directly and powerfully fuelled by the extraordinary emphasis on eschatology in the Tupi-Guarani world (which includes the Guarani nations). Their social life may be relatively simple but the taxonomy of the supernatural world is complex and this spiritual dimension has an active, intense presence in quotidian, material life (Viveiros de Castro 1986, 1996). Several scholars who have studied the Guarani have recorded the pre-eminence of religion over all social spheres and, more significantly, the practice of religion as a decisive locus of cultural resistance. The use of their own language, impenetrable to most outsiders, also works as a secret war code that helps to preserve their identity and enforce the meaning of their objects, actions and traditions. New generations are prouder of being indigenous, which is an important legacy of the last four decades of mobilisation and dialogue with allied non-indigenous groups. Clastres (1975) and several other authors have demonstrated the crucial role of religion in the rationalisation of dramatic socio-spatial changes that have affected the Guarani. Their religious beliefs are centred around the messianic expectation of the 'land without evil' that will eventually replace the imperfect, mundane reality of the lived world (although this myth has been questioned as a decontextualized academic fabrication: see Villar and Combès 2013). Guarani cosmology is also informed by the apocalyptic vision of the end of the world, now often associated with the inferno of monoculture farms (Morais 2017).

Benites (2014), an indigenous scholar, provides a vivid description of the violence historically experienced by the Kaiowa, but also the sophisticated preparation for retomadas, making use of cultural and religious heritages as an integrating and transformative force. The aim of the retomada is to restore the lost tekoha guassu, which is the territory shared by several extended families following influential religious and political leaders. From the narrative offered by Benites, it is possible to ascertain the crucial political and existential connection between families and their leadership revealed in the tekoha - tekoha guassu dialectics. The strategies of land reoccupation are intensely discussed and enacted in the large assemblies (aty guassu) organised by the Kaiowa since 1979, in which religious rituals are of paramount importance. Participants identify mutual needs, share tactics, make collective decisions, and prepare documents for public dissemination. The passionate ritualization of their practices and the importance of religion for their political action encourage them to fight. This is a moment of great risk, a real war, but it is more than a holy war against the invaders: it is a necessary struggle to maintain their world. During the aty guassu, the core assault group is selected, formed by religious people, their assistants, political chiefs, elders and children. This vanguard party spend months preparing themselves for the attack, praying and taking part in strenuous rituals. The four nights before the retomada is a time of even more intense religiosity, when the warriors are baptised, a procedure required for them to be recognised and accepted by the dead ancestors and to be protected against evil spirits and invisible beings. The night before, they paint their faces and parts of the body with urucum (a plant used to make red body paint) and the men hold their bows and arrows tightly as a sign of respect for the ancestors. After this lengthy preparation, they march for around ten kilometres during the night to collectively retake the land. If everything goes as planned, they immediately build huts and start to fish and hunt to feed the group. A new altar for the continuation of religious ceremonies is also erected. Using tactics like these, the Kaiowa have managed to recover more than 20 areas in recent years, although the farmers who claim ownership of the land have reacted in different ways, frequently through the use of brutal violence (many dozens of indigenous leaders have been murdered because of this open war, including Benites's own father, who died in mysterious circumstances). In the end, this is the dialectics of suffering and healing that profoundly marks the contemporary frontiers of capitalism. 


\section{Conclusions}

The previous pages have examined how the straightforward image of modernity and innovation that underpins contemporary development frontiers needs to be replaced with a much more complex picture. Frontier making, which has been a core politico-spatial driving force of capitalist development, remains a highly paradoxical phenomenon, in which progress and abundance are repeatedly promised, while the reality on the ground continues to be shaped by the old practices of exploitation, exclusion and racism. The landscape of the frontier seems simultaneously logical, organised and chaotic, out of place. In the case of Mato Grosso do Sul, agribusiness appears novel, but in fact recreates elements of the colonial past, particularly in the context of violence against local indigenous groups. The Kaiowa-Guarani, along with other peoples, are commonly depicted as living examples of stone-age savages, although their geographical practices demonstrate a sophisticated ability to comprehend and creatively react to socio-spatial pressures and economic changes. It is a situation fraught with puzzles and ambiguities. To a large extent, it is the Kaiowa who are offering innovation, while agribusiness encompasses inbuilt obsolescence. Agribusiness seems new, but it mobilises and is justified through practices introduced in colonial times, while indigenous people are historically old, but their reactions, creativity and aspirations are closely connected with contemporary debates on alternatives to development, market globalisation and cultural homogenisation. All this is happening in a highly politicised landscape where indigenous groups, despite all the tragedy, suffering, humiliation and severe neglect by the state, are in effect securing small, but precious, territorial victories. To the surprise of some urban and business groups, the Kaiowa have shown latent geographical agency shaped by religious practices, strong family ties and the ability to internally negotiate the return to their original areas. The wisdom and resistance of Kaiowa-Guarani groups derive from the simultaneous ethnicisation of space and spatialisation of culture. Far from any sentimental romanticism, we learn that for the last forty years the Kaiowa have been able to regain confidence, mobilise their language, culture and religion, and form strong networks between families and localities to both resist the trend of violence and, when opportunities arise, retake their long lost land.

Different indigenous groups will have diverse levels of association with the Westernised model of economic development (for an overview of development biases, see Escobar 2012). However, the manifestation of indigenous culture represents a challenge to the prospects of frontier making and reveals its ingrained contradictions in terms of socio-ecological violence, social exclusion and inequalities. Contrasting with the narrow rationality of agribusiness farmers and their political allies, the cosmovision of the Kaiowa encapsulates multiple layers in which the material and spiritual terrains converge in a way that allows them not only to labour in the areas currently occupied, but also to almost touch the spectral space that will be returned to them one day. The land of their ancestors belongs to the living descendants and the return to those areas depends, fundamentally, on the initiative and courage of present generations. Because Kaiowa land has a purely qualitative value, which is absolute, perpetual and beyond monetisation, the only logical attitude is to continue the struggle to the very last drop of blood. From their perspective, they are witnessing a 'territorial pulse': that is, their lands are only temporarily lost and are there to be reconquered. The Kaiowa never gave up their land - indeed, they could not, because it is part of their existence to be returned to the ancestral land. There are many lessons to be learnt here, in particular the talent of the Kaiowa to absorb the increasing and dissimulated brutality of frontier making and, at the same time, voice their political demands, form solid strategic alliances and coordinate land-recovery initiatives. The affirmation of indigenous identities and the pursuit of long-pending rights are relatively recent phenomena in Brazil and other South American countries, directly associated with the progressive strengthening of democratic reforms. In this context, the resistance and agency of indigenous groups, who are increasingly trying to restore valued elements lost to national development, are crucial components of a wider mobilisation for social and environmental justice. 
The results of this analysis endorse the growing importance of indigenous geography in the early twenty-first century, a period characterised by sustained attacks on many of the important social and political achievements of the last two centuries (such as universal equality, rejection of racism and discrimination, basic human rights, etc.). The territorial and agrarian struggle of the Kaiowa-Guarani constitutes an emblematic chapter of a geographical mobilisation in the Global South of the planet that challenges the conventional, Westernised narrative of modernity or post-modernity (Ioris 2018c). The survival and expansion of groups like the Kaiowa actually represent an 'inconvenient' reminder that other worlds are possible and, quite conceivably, necessary. As social, ethical and political tensions increase, perhaps Brazilians can find helpful responses from those traditionally ignored: the descendants of the early inhabitants of the continent, who may hold answers to some of the problems accumulated through a highly uneven process of national development. Indigeneity is a relational construct, and, because of the incomplete erasure of colonisation, indigenous and non-indigenous identities co-constitute each other (Coombes et al. 2011). The Kaiowa, other Guarani populations and the more than 300 first nation peoples have much to offer in the collective search for a more meaningful way of life. Perhaps a biblical analogy can even be invoked in this context: non-indigenous Brazilians are the prodigal sons and the indigenous peoples the wise fathers (Figure 9). A huge dose of humility and willingness to learn will certainly be needed in order to move beyond the tragic geography of frontier making.

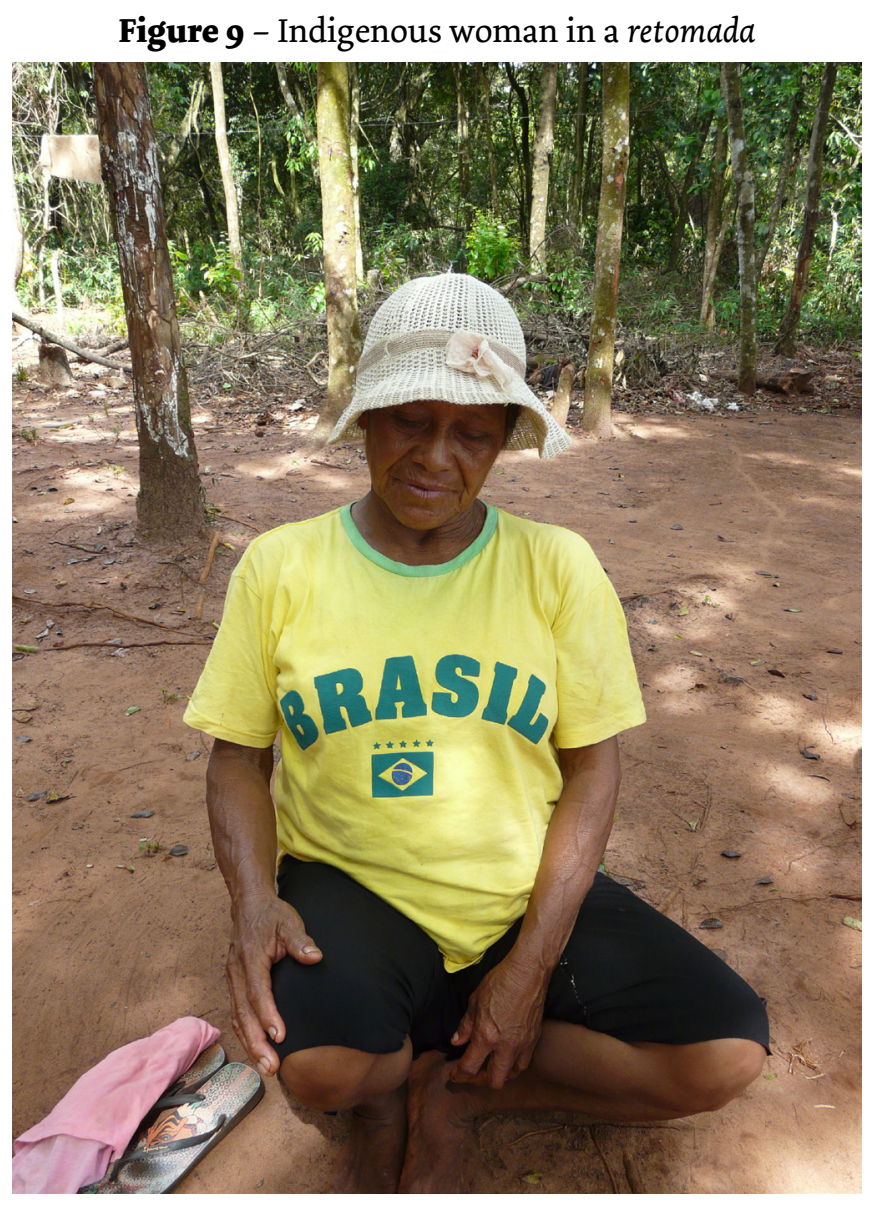

Received: July 26, 2019

Approved: October 08, 2019

Revised by David Rodgers 


\section{References}

ANTHIAS, P. 2017. "Ch'ixi Landscapes: Indigeneity and Capitalism in the Bolivian Chaco". Geoforum, 82: 268275.

BARBOSA, P.A.; MURA, F. 2011. “Construindo e Reconstruindo Territórios Guarani: Dinâmica Territorial na Fronteira entre Brasil e Paraguai (Séc. XIX-XX)”. Journal de la Société des Américanistes, 97(2): 287-318.

BENITES, T. 2014. "Recuperação dos Territórios Tradicionais Guarani-Kaiowá: Crónica das Táticas e Estratégias". Journal de la Société des Américanistes, 100(2): 229-240.

BRAND, A. 1997. O Impacto da Perda da Terra Sobre a Tradição Kaiowá/Guarani: Os Difíceis Caminhos da Palavra. $\mathrm{PhD}$ thesis. PUCRS: Porto Alegre.

. 1998. “'Quando Chegou esses que são Nossos Contrários': A Ocupação Espacial e o Processo de Confinamento dos Kaiowá/Guarani no Mato Grosso do Sul”. Multitemas, 12: 21-51.

CAVALCANTE, T.L.V. 2014. "Demarcação de Terras Indígenas Kaiowá e Guarani em Mato Grosso do Sul: Histórico, Desafios e Perspectivas". Fronteiras: Revista de História, 16: 48-69.

CHAMORRO, G. 1998. A Espiritualidade Guarani: Uma Teologia Ameríndia da Palavra. Sinodal: São Leopoldo. . 2010. "Imagens Espaciais Utópicas: Símbolos de Liberdade e Desterro nos Povos Guarani". Indiana, 27: 79-107.

CIMI. 2001. Conflitos de Direitos sobre as Terras Guarani Kaiowa no Estado do Mato Grosso do Sul. São Paulo: Conselho Indigenista Missionário.

CIMI. 2018a. Violência contra os Povos Indígenas no Brasil: Dados de 2017. Brasília: Conselho Indigenista Missionário.

CIMI. 2018b. Congresso Anti-Indígena: Os Parlamentares que mais Atuaram Contra os Direitos dos Povos Indígenas. Available at: https://cimi.org.br/wp-content/uploads/2018/og/congresso-anti-indigena.pdf. Consulted on: o2 Oct 2018.

CLASTRES, P. 1974. Le Grand Parler: Mythes et Chants Sacrés des Indiens Guarani. Paris: Editions du Seuil.

CLASTRES, H. 1975. La Terre Sans Mal: Le Prophétisme Tupi-Guarani. Paris: Editions du Seuil.

COOMBES, B. et al. 2011. "The Challenges of and from Indigenous Geographies". In: V. J. Del Casino, M.

Thomas, P. Cloke and R. Panelli (eds.), The Companion to Social Geography. Blackwell: Oxford. pp. 523-542.

COOMBES, B.; JOHNSON, J.T.; Howitt, R. 2014. "Indigenous Geographies III: Methodological Innovation and the Unsettling of Participatory Research". Progress in Human Geography, 38(6): 845-854.

DE LA CADENA, M. 2010. "Indigenous Cosmopolitics in the Andes: Conceptual Reflections beyond 'Politics"'. Cultural Anthropology, 25(2): 334-370.

DELEUZE, G. 1968. Différence et Répétition. Paris: PUF.

DOYLE, C.M. 2015. Indigenous Peoples, Title to Territory, Rights and Resources. London: Routledge.

EGOZ, S.; MAKHZOUMI, J.; PUNGETTI, G. (eds.). 2011. The Right to Landscape: Contesting Landscape and Human Rights. London and New York: Routledge.

EMGC (Equipe Mapa Guaraní Continental). 2016. Cuaderno del Mapa Guaraní Continental: Pueblos Guaraníes en Argentina, Bolivia, Brasil y Paraguay. Campo Grande: EMGC.

ESCOBAR, A. 2012. Encountering Development: The Making and Unmaking of the Third World. Princeton and Oxford: Princeton University Press.

FERREIRA, A.C. 2007. Tutela e Resistência Indígena: Etnografia e História das Relações de Poder entre os Terena e o Estado Brasileiro. PhD thesis. Museu Nacional/UFRJ: Rio de Janeiro.

FUHRMANN, L. 2018. Ameaças e Ataques a Indígenas e Sem-terra Marcam Fim de Semana da Vitória de Bolsonaro. Available at: https://deolhonosruralistas.com.br/2018/10/29/ameacas-e-ataques-a-indigenas-e-sem-terramarcam-fim-de-semana-da-vitoria-nas-urnas-de-bolsonaro. Consulted on: 05 Nov 2018. 
GALEANO, E. 1982. Memorial del Fuego I: Los Nacimientos. Madrid: Siglo XXI.

INGOLD, T. 1993. "The Temporality of the Landscape". World Archaeology, 25(2): 152-174.

IORIS, A.A.R. (ed.). 2012. Tropical Wetland Management: The South-American Pantanal and the International Experience. Farnham, Surrey: Ashgate.

. 2017. Agribusiness and the Neoliberal Food System in Brazil: Frontiers and Fissures of Agro-neoliberalism.

London: Routledge.

. 2018a. "Amazon's Dead Ends: Frontier making the Centre". Political Geography, 65: 98-106.

2018b. "The Politics of Agribusiness and the Business of Sustainability". Sustainability, 10(5): 1648;

doi:10.339o/su10051648

. 2018c. "Seeding a Narrow Future and Harvesting an Exclusionary Past: The Contradictions and

Future Scenarios of Agro-neoliberalism in Brazil”. Futures, 95: 76-85.

. 2019. "Peasant Farming in the Southern Tracts of the Amazon: The Reluctant Alterity of

Agribusiness". Perspectives on Global Development and Technology, 18: 375-400.

JACKSON, P.; PENROSE, J. (eds.). 1993. Constructions of Race, Place and Nation. Minneapolis: Minnesota

University Press.

LARSEN, S.C.; JOHNSON, J. T. 2012. "Between Worlds: Place, Experience, and Research in Indigenous

Geography”. Journal of Cultural Geography, 29(1): 1-13. . 2017. Being Together in Place. Minneapolis: University of Minnesota Press.

LENNOX, C.; SHORT, D. (eds.). 2016. Handbook of Indigenous People's Rights. London and New York: Routledge.

LÖWY, M.; SAYRE, R. 2018. "Raymond Williams, Romanticism and Nature”. Capitalism Nature Socialism, 29(2): 75-91.

MARIÁTEGUI, J.C. 2007 [1928]. Siete Ensayos de Interpretación de la Realidad Peruana. Caracas: Fundación Biblioteca Ayacucho.

MARKUS, C. (ed.). 2013. Kaiowá: Um Povo que Caminha. São Leopoldo: ISAEC/DAÍ-COMIN

MARTINS, J.S. 1995. Os Camponeses e a Política no Brasil. 5th ed. Petrópolis: Vozes.

MACDONALD, K. 2017. "My Experiences with Indigenist Methodologies”. Geographical Research, $55(4): 369-378$.

MELIÀ, B. 2004. "El Pueblo Guaraní: Unidad y Fragmentos”. Tellus, 6: 151-162.

MORAIS, B.M. 2017. Do Corpo ao Pó: Crônicas da Territorialidade Kaiowá e Guarani nas Adjacências da Morte. São Paulo: Elefante.

MURA, F. 2006. À Procura do "Bom Viver”: Território, Tradição de Conhecimento e Ecologia Doméstica entre os Kaiowa. PhD thesis. Museu Nacional/UFRJ: Rio de Janeiro.

MURTON, B. 2012. "Being in the Place World". Journal of Cultural Geography, 29(1): 87-104.

OCHIGAME, R.; HOLSTON, J. 2016. “Filtering Dissent: Social Media and Land Struggles in Brazil”. New Left Review, 99: 85-108.

OLIVEIRA, J.P. 1983. “Terras Indígenas no Brasil: Uma Tentativa de Abordagem Sociológica”. Boletim do Museu Nacional - Antropologia, 44: 1-28. . 2018. "Fighting for Lands and Reframing the Culture". Vibrant, 15(2): 1-21.

PANELLI, R. 2008. "Social Geographies: Encounters with Indigenous and More-than-White/Anglo Geographies". Progress in Human Geography, 32(6): 801-811.

PARSON, S.; RAY, E. 2018. "Sustainable Colonization: Tar Sands as Resource Colonialism”. Capitalism Nature Socialism, 29(3): 68-86.

PEREIRA, L.M. 2010. "Demarcação de Terras Kaiowa e Guarani em MS: Ocupação Tradicional,

Reordenamentos Organizacionais e Gestão Territorial”. Tellus, 18: 115-137. 
2016. Os Kaiowá em Mato Grosso do Sul: Módulos Organizacionais e Humanização do Espaço Habitado.

Dourados: UFGD.

QUIJANO, A. 2008. "El Movimiento Indígena y las Cuestiones Pendientes en América Latina". Cotidiano -

Revista de la Realidad Mexicana, 151: 107-120.

RADCLIFFE, S. A. 2017. “Geography and Indigeneity I: Indigeneity, Coloniality and Knowledge”. Progress in

Human Geography, 41(2): 220-229.

RAMOS, A. R. 1994. “The Hyperreal Indian”. Critique of Anthropology, 14(2): 153-171.

. 2018. "Por una Crítica Indígena de la Razón Antropológica". Anales de Antropología, 52(1): 59-66.

RIBEIRO, D. 2015. O Brasil como Problema. 2nd ed. São Paulo: Global.

RIDDELL, J.K. et al. 2017. "Laying the Groundwork: A Practical Guide for Ethical Research with Indigenous

Communities". The International Indigenous Policy Journal, 8(2); doi:10.18584/iipj.2017.8.2.6

ROGERS, T.J.; BAIN, S. 2016. "Genocide and Frontier Violence in Australia”. Journal of Genocide Research, 18(1):

83-100.

SHAW, W.S.; HERMAN, R.D.K.; DOBBS, G.B. 2006. "Encountering Indigeneity: Re-imagining and

Decolonizing Geography”. Geografiska Annaler: Series B, Human Geography, 88(3): 267-276.

SHORT, D. 2016. Redefining Genocide: Settler Colonialism, Social Death and Ecocide. London: Zed Books.

SILVA, A.B. 2007. Mais Além da "Aldeia": Território e Redes Sociais entre os Guarani de Mato Grosso do Sul. PhD

thesis. Museu Nacional/UFRJ: Rio de Janeiro.

SMITHERS GRAEME, C.; MANDAWE, E. 2017. "Indigenous Geographies: Research as Reconciliation”.

International Indigenous Policy Journal, 8(2); doi:10.18584/iipj.2017.8.2.2

THOMPSON, E.P. 1993. Customs in Common. New York: New Press.

VAN KRIEKEN, R. 2004. "Rethinking Cultural Genocide: Aboriginal Child Removal and Settler-Colonial State Formation". Oceania, 75(2): 125-151.

VIETTA, K. 2013. "Histórias Territoriais: A Privatização das Terras Kaiowa como Estratégia para a Guarnição da Fronteira Brasileira e Outras Histórias". Espaço Ameríndio, 7(2): 26-63.

VILLAR, D.; COMBÈS, I. 2013. “La Tierra Sin Mal. Leyenda de la Creación y Destrucción de un Mito”. Tellus, 24: 201-225.

VIVEIROS DE CASTRO, E.B. 1986. Araweté: Os Deuses Canibais. Rio de Janeiro: Jorge Zahar. . 1996. "Images of Nature and Society in Amazonian Ethnology". Annual Review of Anthropology, 25:

179-200.

WOOLFORD, A.; THOMAS, J. 2017. "Genocide of Canadian First Nations”. In: S. Totten and R. K. Hitchcock

(eds.), Genocide of Indigenous Peoples). London and New York: Routledge. pp. 61-85.

YIFTACHEL, O.; FENSTER, T. 1997. "Frontiers, Planning and Indigenous Peoples". (Introduction to a Special Issue). Progress in Planning, 47: 251-258.

ZELIC, M. 2018. Um Genocídio em Curso no Mato Grosso do Sul. Cartografia dos Ataques Contra Indígenas (CACI). Available at: http://caci.cimi.org.br. Consulted on: 27 Sep 2018.

Antonio A. R. loris

Professor (reader)

Cardiff University, School of Geography and Planning

Glamorgan Building, King Edward VII Avenue

Cardiff, CF10 3WA, Wales, United Kingdom

Author's email: IorisA@cardiff.ac.uk

https://orcid.org/oooo-0003-0156-2737 